\title{
Phenylenediamine-based bivalent glycocyclophanes: synthesis and analysis of the influence of scaffold rigidity and ligand spacing on lectin binding in cell systems with different glycomic profiles $\dagger$
}

\author{
Sabine André, ${ }^{a}$ Trinidad Velasco-Torrijos, ${ }^{b}$ Rosaria Leyden, ${ }^{b}$ Sebastien Gouin, ${ }^{b}$ Manuela Tosin, ${ }^{b}$ \\ Paul V. Murphy*b,c and Hans-Joachim Gabius ${ }^{a}$
}

Received 1st July 2009, Accepted 17th August 2009

First published as an Advance Article on the web 23rd September 2009

DOI: 10.1039/b913010a

The conjugation of carbohydrates to synthetic scaffolds has the goal of preparing potent inhibitors of lectin binding. We herein report the synthesis of a panel of bivalent compounds (cyclophane and terephthalamide-derivatives) then used to establish the influence of scaffold flexibility on respective inhibitory potency in a medically relevant test system. Synthetic routes to two phenylenediamine-based glycocyclophanes involving Ugi reactions of glucuronic acid derivatives and subsequent ring closing metathesis are described, as are improvements for producing terephthalamide-based carbohydrate carriers. Assays were performed with human tumour cells measuring quantitatively the influence of the test compounds on fluorescent surface staining by labelled lectins. Biological evaluation using two different lines of cancer cells as well as cells with known alterations in the glycomic profile (cells treated with an inhibitor of glycan processing and a glycosylation mutant) reduced the risk of generating premature generalizations regarding inhibitor potency. Bioactivity relative to free mannose was invariably determined for the synthetic compounds. A clear trend for enhanced inhibitory properties for macrocyclic compounds compared to non-macrocyclic derivatives was discerned for one type of glycocyclophane. Herein we also document the impact of altering the spacing between the mannose residues, altering cell surface ligand density and cell-type reactivity. The applied strategy for the cell assays is proposed to be of general importance in the quest to identify medically relevant lectin inhibitors.

\section{Introduction}

The ideal chemical properties of carbohydrates to generate an unsurpassed structural biodiversity of oligomers and to engage in intermolecular interactions underlie the concept of the sugar code. ${ }^{1}$ Indeed, glycans of cell surface glycoproteins are versatile biochemical signalling molecules by serving as direct contact site for receptors with carbohydrate specificity (trans-interactions) and as potent molecular switches regulating the protein component's accessibility and functionality ( $c$ is-interactions). ${ }^{1,2}$ Even seemingly minor structural changes in these complex carbohydrates, such as a core substitution in $N$-glycans, trigger significant alterations in glycan conformations and lectin affinity. ${ }^{3}$ Underlining their salient role for cellular communication, several cases have been elucidated in which orchestrated changes in glycan display and expression of the cognate lectin cooperate to turn sugar-encoded information swiftly into cellular responses such as apoptosis induction or autoimmune suppression. ${ }^{4}$ Considering the multiple,

Institute of Physiological Chemistry, Faculty of Veterinary Medicine, Ludwig-Maximilians-University Munich, Veterinärstr. 13, 80539 Munich, Germany

${ }^{b}$ School of Chemistry and Chemical Biology, Centre for Synthesis and Chemical Biology, University College Dublin, Belfield, Dublin 4. E-mail: paul.v.murphy@nuigalway.ie; Fax: +353(0)91525700

'School of Chemistry, National University of Ireland, Galway, University $R d$, Galway

$\dagger$ Electronic supplementary information (ESI) available: Experimental details, NMR spectra. See DOI: 10.1039/b913010a medically relevant activities of cell surface glycans in regulating e. $g$. adhesion, migration, proliferation or tissue invasion, it is an attractive aim to develop strategies to efficiently interfere with the binding of certain effectors to cell surface glycans. In other words, the issue to define structure-activity relationships for lectinblocking compounds is of fundamental importance, especially at the level of cell surfaces which represent the physiological platform for the interaction process.

Toward this end, we herein put the question to the experimental test whether and how intramolecular flexibility of distinct scaffolds carrying two docking sites for a model lectin affects its cell surface binding. In detail, we compare two rather flexible bivalent compounds (1a, 3a) with the corresponding rigid glycocyclophanes (2a, 4a/4b) (Fig. 1), the central synthetic and cell biological part of our report. In addition, other phenylenediamine-based bivalent compounds (5a, 10) and the monovalent compound (6a) were used as controls (Fig. 1). The impact of scaffold design on bioactivity is further evaluated by testing four bivalent terephthalamide-based compounds (7c, 7d, 8, 9) ${ }^{5}$ and the bivalent mannoside 11, based on a tetraethylene glycol scaffold (Fig. 1). The selection of the bivalent ligand systems was based on choosing scaffolds with varying degrees of rigidity with a view to exploring how changing both rigidity and the spatial presentation of ligand would alter inhibition of lectin binding. The spatial relationship between the two mannose ligands in the two most constrained systems $\mathbf{2 a}$ and $\mathbf{4 a}$ is shown to be significantly different. The linkage patterns of the mannose ligands and thus spatial relationship between these 


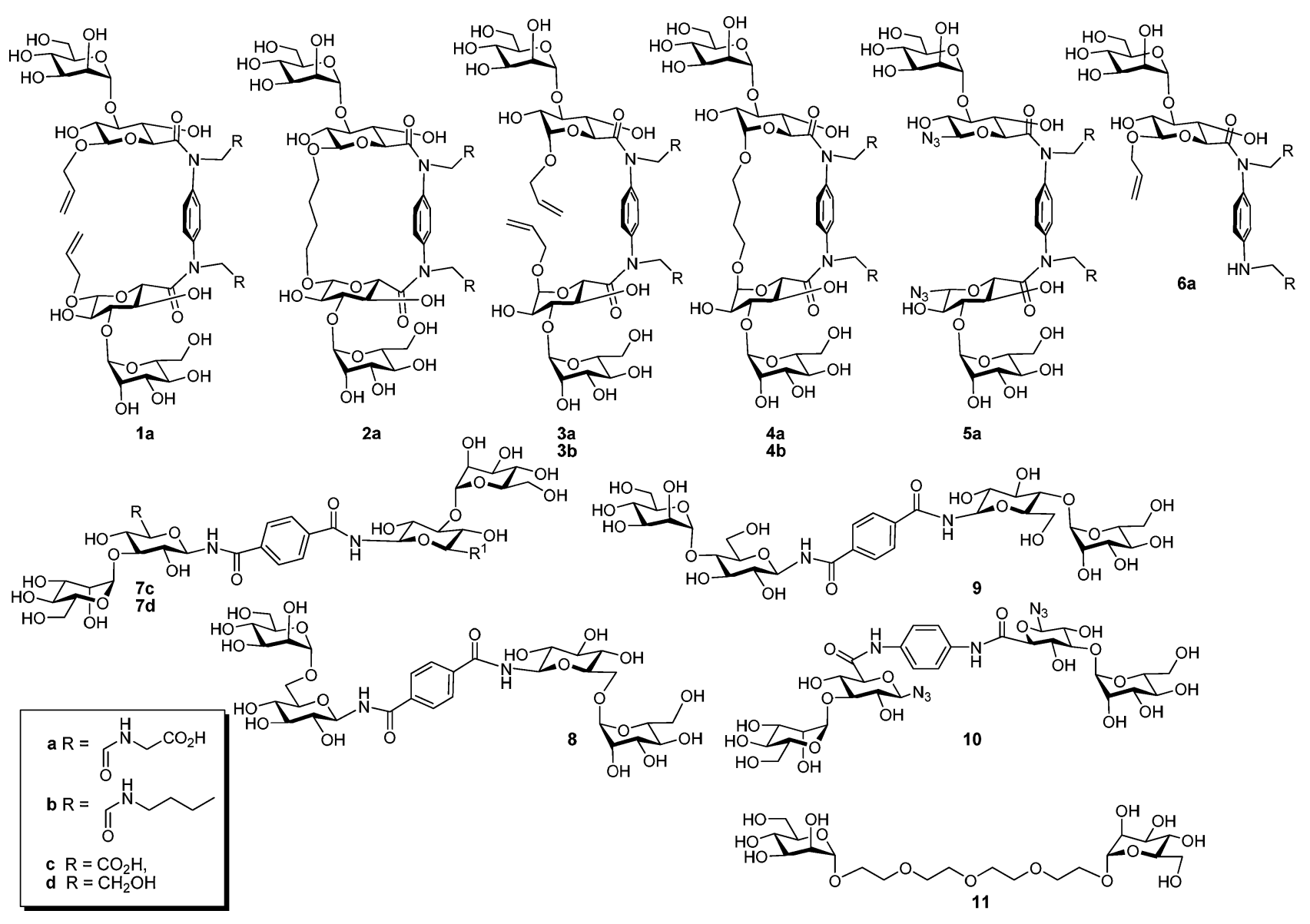

Fig. 1 Structures of the test panel.

residues is also different when comparing the terephthalamides 7-9, of which the initial synthetic and structural aspects were reported previously. ${ }^{5}$ Since glycan display on cells is physiologically subject to dynamic changes, the design of suitable assays is a key factor to assess inhibitory capacity of any compound. It should account for shifts in the glycomic profile to reach valid conclusions. Consequently, our respective efforts were guided by the intention to introduce systems with deliberately tunable affinity and density of cell surface ligands with a view to evaluating glycocompound potency. Naturally, these two characteristics can have a bearing on the competition between the synthetic agent and cell surface glycans for binding to the lectin. Thus, a more general inhibitory trend for a synthetic ligand warrants being investigated and this can be achieved by adequate tailoring of the test system. Toward this aim, treatment of cells with an inhibitor of glycan processing as well as using a cell type expressing a suitable glycosylation mutant ${ }^{2 g}$ are both viable options to alter glycomic profile by altering $N$-glycan structure on the cell surface. Hereby, the cell surface density of mannose residues and the presentation of truncated complex-type $N$-glycans, respectively, are increased. These changes will enhance binding of the test lectin concanavalin A (ConA), facilitating inhibitory assays using cells with different glycomic profiles. In detail, the binding of the labelled lectin to native cells is monitored automatically on the single-cell level by fluorescent staining, and an inhibitor, blocking lectin-binding, will decrease staining intensity.
Experimentally, the lectin's binding parameters to cells (mean fluorescence intensity of stained cells and percentage of positive cells) and reactivity to inhibitors were determined for two different human tumour cell lines to trace cell-type-dependent alterations. If the sugar derivatives maintain their bioactivity, then the presence of a glycocompound will reduce fluorescent cell surface staining by the labelled lectin, and these activities are routinely compared to that of free mannose as the reference value. The two approaches to cell surface ligand remodelling then enabled to derive a relationship between the observed inhibitory activity observed for a synthetic compound to changes in the profile of $N$-glycans. More specifically, we shifted the glycomic profile of one tumour cell system to high-mannose-type $N$-glycans by applying the mannosidase I inhibitor 1-deoxymannojirimycin and additionally tested the glycosylation mutant Lec8 of the Chinese hamster ovary system. The latter presents high-affinity ligands for ConA constituted by the $N$-acetylglucosamine (GlcNAc)terminated trimannoside core. ${ }^{6}$

\section{Results and discussion}

\section{Synthesis}

The various rigid and flexible compounds $\mathbf{1}-\mathbf{5}$ for the presentation of the mannose ligand were envisaged to be accessible via Ugi reactions of glucuronic acid derivatives. As the first step, the syntheses of required building blocks $(\mathbf{1 4}, \mathbf{1 8}, 19)$ were carried out. 
In detail, the glycosidation of trichloroacetimidate $\mathbf{1 2}^{7}$ promoted by boron trifluoride etherate in the presence of allyl alcohol generated the allyl glycoside with $\beta$-configuration. Saponification and subsequent treatment of the product with acetic anhydride gave a 6,3-lactone derivative as an intermediate. This lactone was converted to $13^{17-19}$ by reaction with allyl alcohol in presence of molecular sieves and sodium acetate. Glycoside bond-forming reaction of 13 with the Schmidt-Michel donor $15^{8}$ gave the expected $\alpha$-glycoside product in good yield, and subsequent selective hydrolysis of the allyl ester using $\mathrm{Pd}(0)$ catalysis $^{9}$ resulted in 14 (Scheme 1).

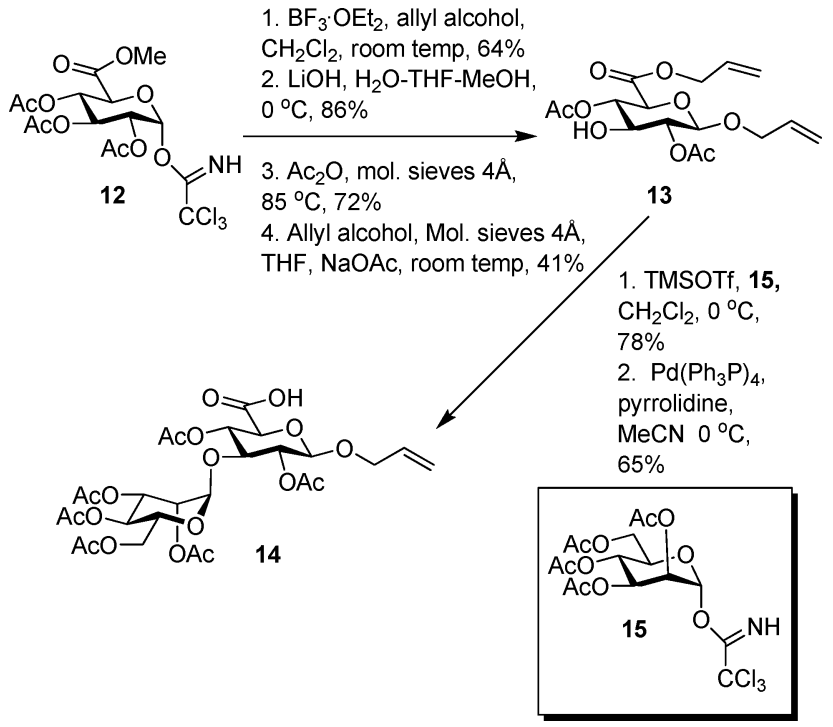

Scheme 1 Synthesis of 14.

The $\alpha$-glycoside 16, prepared as described previously ${ }^{10}$ was treated with sodium methoxide in $\mathrm{MeOH}$, then acetylation produced a 6,3-lactone derivative analogous to 12, except for its $\alpha$-configuration. Subsequent reaction of this lactone intermediate with allyl alcohol in the presence of molecular sieves and sodium acetate produced glycosyl acceptor 17. Glycosidation using the trichloroacetimidate donor $\mathbf{1 5}$ and subsequent $\mathrm{Pd}(0)$-catalysed hydrolysis of the allyl ester as before gave $\mathbf{1 8}$ (Scheme 2). The azide derivative 19 was prepared by literature procedure. ${ }^{5 d}$

With these carboxylic acid derivatives in hand we were able to generate divalent structures using Ugi reactions. This approach to the bivalent tertiary anilides was superior to other routes investigated. The less successful routes included amide coupling reactions of 1,4-phenylenediamine with glucuronic acid derivatives and efforts to subsequently alkylate the amides. In contrast, the Ugi reactions of 14, 18 and 19 with formaldehyde, phenylene1,4-diamine and methyl isocyanoacetate proceeded efficiently to give 20a-22b (Scheme 3). The $N$-butyl derivative 21b (structure shown in Scheme 4) was obtained from the corresponding Ugi reaction of $\mathbf{1 8}$ with $n$-butylisocyanide. Removal of ester-protecting groups from 20a-22b proved difficult due to competing cleavage of the tertiary anilides. The hydrolysis product $\mathbf{6 a}$, for example, was generated from attempts to convert 20a into 1a using a variety of conditions, including Zemplén deacetylation. The use of triethylamine in the presence of water and $\mathrm{MeOH}$ or $\mathrm{KCN}-$

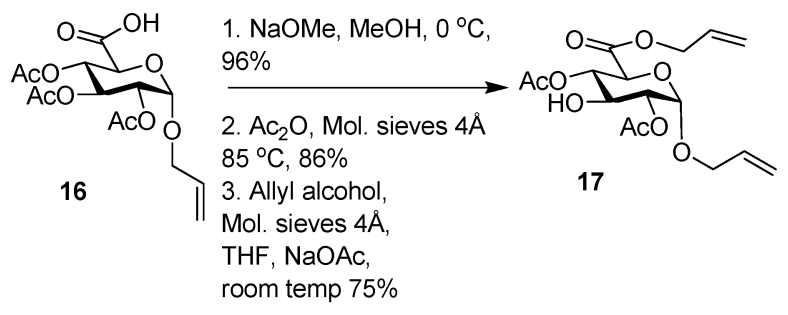

1. TMSOTf, 15,

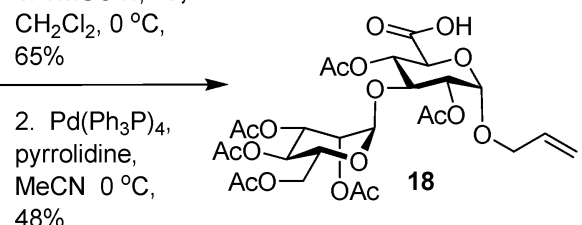

$48 \%$

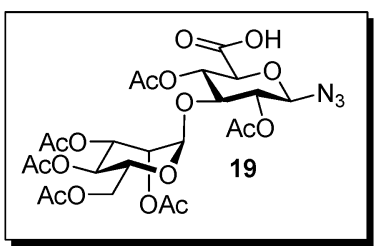

Scheme 2 Synthesis of $\mathbf{1 8}$.
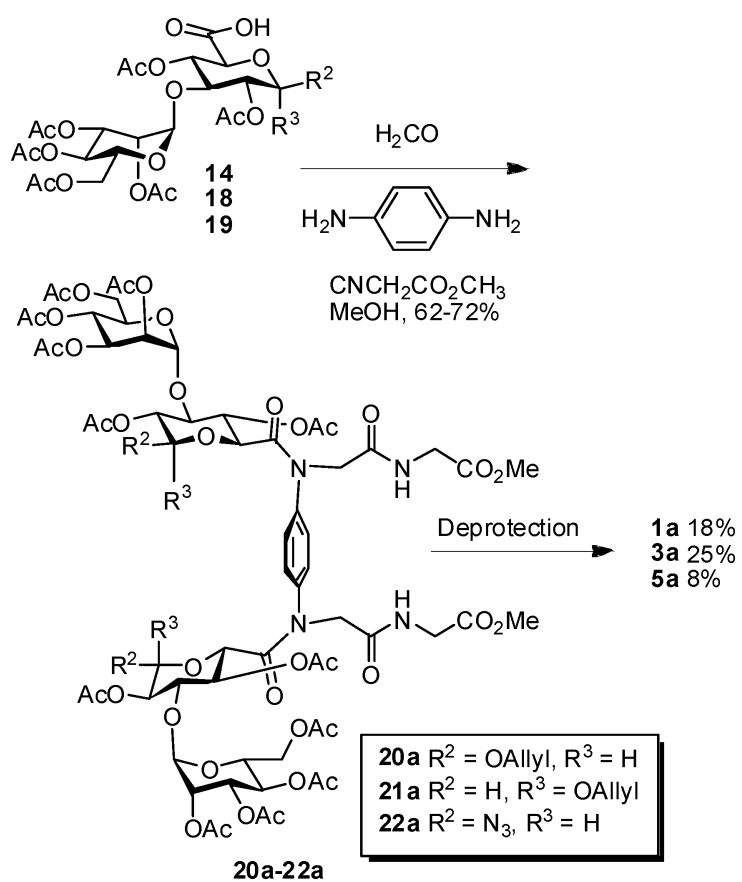

Scheme 3 Synthesis of flexible glycoclusters 1a, 3a and 5a.

$\mathrm{MeOH}$ did ultimately give the bivalent mannosides 1a (18\%), 3a $(25 \%)$ and $\mathbf{5 a}(8 \%)$ in low yields (Scheme 3).

With the mannose derivatives 20a and 21a/21b in hand macrocyclisation was effected using ring-closing metathesis reactions, generating conformationally constrained macrocyclic structures (Scheme 4). The reaction of 20a with the Grubbs-I catalyst (91\%), subsequent catalytic hydrogenolysis $(89 \%)$ and de- $O$-acetylation using $\mathrm{KCN}$ in $\mathrm{MeOH}(11 \%)$ gave 2a (not shown). As in the synthesis of acyclic derivatives 1a and 3a (Scheme 3), it was not possible to prevent competing cleavage of the tertiary anilide intermediate, which was the major reason for the low yields of 


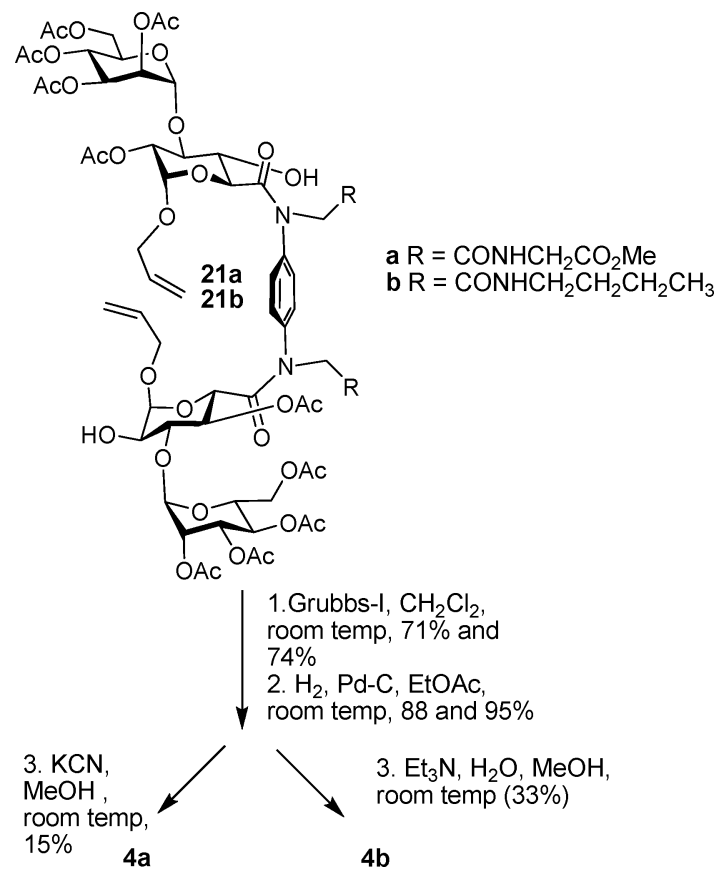

Scheme 4 Synthesis of rigid macrocyclic glycoclusters 4.

the desired macrocyclic glycocyclophane derivatives. A similar sequence from $21 \mathbf{a}$ and $\mathbf{2 1 b}$ gave $\mathbf{4 a}$ and $\mathbf{4 b}$ (Scheme 4), respectively. The yield for the deprotection of the ring-closed product obtained from metathesis of $\mathbf{2 1 b}$, which was achieved with triethylamine in $\mathrm{MeOH}$ and water, was higher than that observed for deprotection of the ring-closed product obtained from 21a, which involved use of $\mathrm{KCN}-\mathrm{MeOH}$.

The synthesis of terephthalamide derivative $\mathbf{7 d}$, adding to prior experience, ${ }^{5 \mathrm{c}}$ was accomplished from diacetone-D-glucose 23 (Scheme 5). Glycosidation of 23 using 15 as donor and with
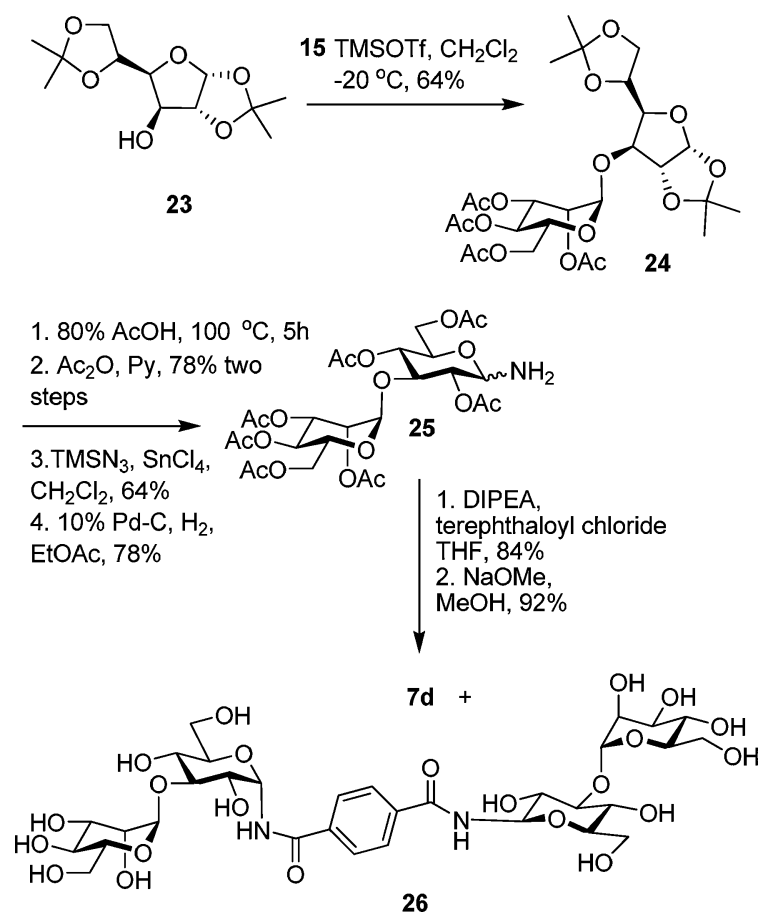

Scheme 5 Synthesis of 7d.
TMSOTf as promoter as acceptor gave $\mathbf{2 4}$. The acetonide groups were then removed by heating in $80 \%$ acetic acid and the deprotected intermediate then acetylated to obtain a per- $O$-acetylated disaccharide, where the glucose residue was in the pyranose form. $\mathrm{Next}$, treatment of this per- $\mathrm{O}$-acetate with azidotrimethylsilane in the presence of a Lewis acid gave a $\beta$-azide intermediate and subsequent catalytic hydrogenation of the azide gave 25 as a mixture of anomers. Coupling of $\mathbf{2 5}$ using freshly recrystallised terephthaloyl chloride proceeded in $84 \%$ yield to produce the acetylated dimeric precursor. Subsequent de- $O$-acetylation using Zemplén conditions proceeded smoothly to give $\mathbf{7 d} ; \mathbf{2 6}$ was also isolated as a by-product from this reaction sequence. This sequence was overall more efficient than that described for preparation of 7c previously. ${ }^{5 \mathrm{c}}$

The synthesis (not shown) of $\mathbf{1 1}$ was achieved by glycosidation of $\mathbf{1 5}$ with tetraethylene glycol as the nucleophile and subsequent deprotection. Having completed the synthetic procedures, we next calculated spatial aspects of ligand presentation.

\section{Spatial parameters of ligand presentation}

The spatial way that mannose residues are presented on the macrocyclic derivatives $\mathbf{2 a}$ and $\mathbf{4 a}$ was inferred computationally. It was expected that the mobility of mannose residues in $\mathbf{2 a}$ and 4a/4b would be significantly more restricted than in both $\mathbf{1 a}$ and 3a. Cyclophane analogues derived from phenylenediamine which incorporate allyl glycosides have been noted to be rigid. ${ }^{10 a}$ The macrocyclic scaffold of $\mathbf{2 a}$ contains two internal $\beta$-linked glucuronic acid residues, whereas that in $\mathbf{4 a}$ contains two internal $\alpha$-linked glycosides. The effect of these scaffold configurational differences on the spatial parameters of mannose presentation was explored by molecular modelling. Low-energy conformations of the core scaffold structures were first generated using conformational searching techniques and energy minimization in Macromodel. The mannose residues were then incorporated so that glycosidic bond torsion angles defining the linkage between the mannose residues and the glucuronic acid residue were consistent with low-energy structures for related disaccharides, which had been calculated using the OPLS-AA force field in Macromodel. ${ }^{11}$ One of the mannose residues of $\mathbf{2 a}$ was then superimposed with one of the mannose residues of $\mathbf{4 a}$, and the overlapped model structures are shown in Fig. 2. The modeling shows that the spatial relationship between the two mannose residues in $\mathbf{2 a}$ is clearly distinct from that in 4a. The distance (Man C-1 to Man $\mathrm{C}-1)$ between the mannose residues in $\mathbf{2 a}$ is $15.4 \AA$, whereas the equivalent distance in $\mathbf{4 a}$ is $13.0 \AA$. Two other parameters were selected to define ligand spatial presentation: (a) the dihedral angle defined by the glycosidic bonds to the two mannose residues (C1-O1-O1-C1); (b) the dihedral angle defined by $\mathrm{C} 4-\mathrm{C} 1-\mathrm{C} 1-\mathrm{C} 4$ of the mannose residues. For $2 \mathrm{a}$ these parameters were $83^{\circ}$ and $-66^{\circ}$, respectively, whereas for $4 \mathbf{a}$ these correspondingly were $-2^{\circ}$ and $-141^{\circ}$. To next prove bioactivity of the prepared compounds and to trace structure-activity correlations of biological relevance cell-binding assays were systematically performed.

\section{Cell assays}

Biological responses are triggered by binding of lectins to cell surface glycans. Obviously, this process needs to be impaired for 


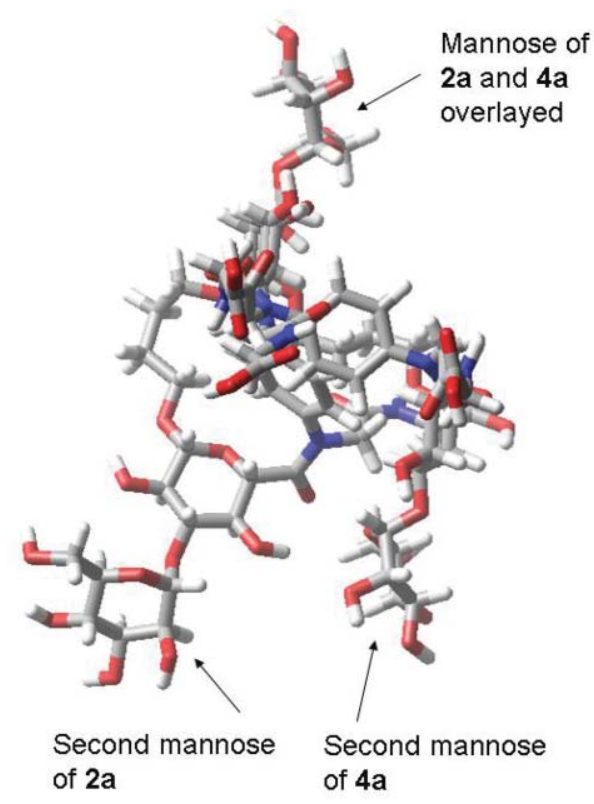

Fig. 2 Models of 2a and 4a superimposed show the different spatial presentation of the mannose ligands.

triggering a therapeutic effect. Labelling of a lectin without activity impairment generates a reliable tool to monitor its association with cell surfaces. The extent of carbohydrate-dependent cell binding is experimentally determined by fluorescent staining in FACScan analysis, obtaining the percentage of positive cells and signal intensity on a logarithmic scale as read-out, as presented in Fig. 3-7. The binding of the labelled lectin will shift the curve representing the staining profile of each lectin-exposed cell population from the position of the control (given as shaded area in each Figure), and presence of an effective inhibitor will move the curve back into the direction of the control. In other words, the two mentioned staining parameters in the graphs will be lowered, if a glycocompound successfully competes with the lectin's docking sites on the cell surface. The result of this competition is best evaluated at a subsaturating lectin concentration in the linear range of concentration dependence, in this case at $1 \mu \mathrm{g} \mathrm{ml} l^{-1}$. It is mandatory to run the assay with aliquots of the same cell batch. As essential controls for the probe's activity, we first ascertained the respective effects of the known haptenic monosaccharides mannose and glucose at this ConA concentration on binding to colon adenocarcinoma cells. Both sugars affected extent of lectin binding (Fig. 3A,B). The direct comparison at $2 \mathrm{mM}$ inhibitor concentration revealed superiority of mannose relative to glucose (Fig. 3C). The measured relative potencies of the two monosaccharide inhibitors reflected their known activities in other assays. ${ }^{6 a}$ Galactose, used as osmolarity control, as expected, did not interfere with lectin activity (not shown). These experimental series validated the assay so that the panel of test compounds could be systematically examined.

In principle, derivatization and attachment of mannose to a variety of different scaffolds did not impair the bioactivity of the mannose residue. However the nature of the scaffold employed did have an influence. Routinely, aliquots of cell batches were studied with the whole panel of compounds to avoid any influence of differences among individual cell preparations. Gradual dif-
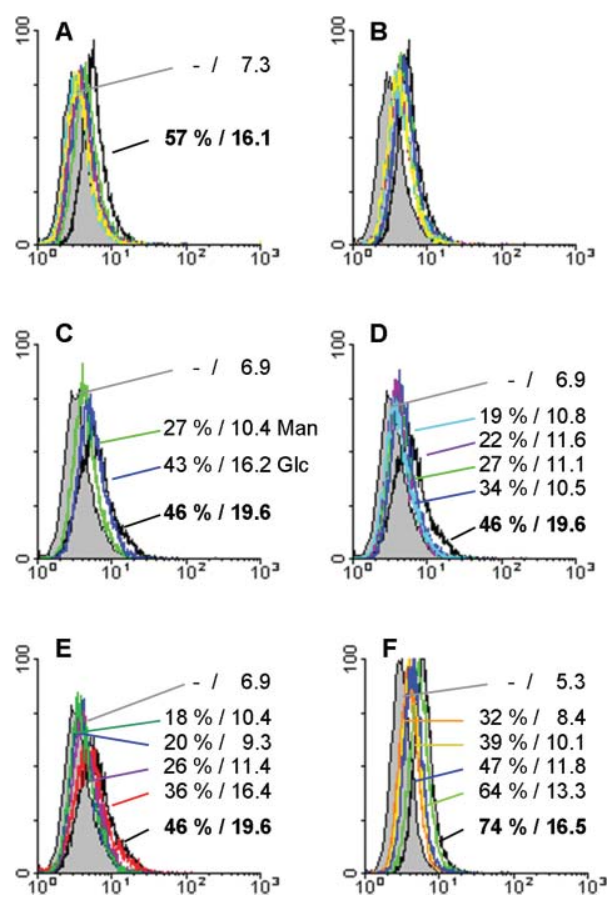

Fig. 3 Semilogarithmic representation of the fluorescent surface staining of cells of the human colon adenocarcinoma line SW480 by $1 \mu \mathrm{g} \mathrm{ml}^{-1}$ labelled ConA. The control value of cell positivity by the second-step reagent in the absence of lectin is given as shaded area, the $100 \%$ value (lectin staining in the absence of inhibitor) as black line. Numbers characterizing staining (percentage of positive cells/mean fluorescence intensity) in each panel are always given in the order of the given listing. A/B: Inhibition of lectin binding by increasing concentrations of mannose (A: $1 \mathrm{mM}, 2 \mathrm{mM}, 4 \mathrm{mM}, 10 \mathrm{mM}, 20 \mathrm{mM}$ ) and glucose (B: $1 \mathrm{mM}, 2 \mathrm{mM}$, $4 \mathrm{mM}, 10 \mathrm{mM}, 20 \mathrm{mM})$. C: Staining parameters in the presence of $2 \mathrm{mM}$ mannose and $2 \mathrm{mM}$ glucose. D: Staining parameters in the presence of $0.5 \mathrm{mM}$ sugar in compounds $\mathbf{6 a}, \mathbf{1 a}, \mathbf{9}$ and $\mathbf{1 1}$ compared to those at $2 \mathrm{mM}$ free mannose in (C). E: Staining parameters in the presence of $0.5 \mathrm{mM}$ sugar in compounds $\mathbf{2 a}, \mathbf{5 a}, \mathbf{4 b}$ and $\mathbf{4 a}$ compared to those at $2 \mathrm{mM}$ free mannose in (C). F: Staining parameters in the presence of $0.1 \mathrm{mM}$ sugar in compounds $6 \mathbf{a}, 2 \mathbf{a}$ and $\mathbf{1 a}$ compared to those at $0.2 \mathrm{mM}$ free mannose.

ferences in binding affinities for synthetic ligands were therefore noted in comparative analyses exemplarily illustrated in Fig. 3D, E. The presentation of mannose in the context of the derivatives increased the lectin-blocking capacity more than fivefold based on the sugar concentration in the assay, with the strongest effects seen already with the monomer 6a (Fig. 3F). Macrocycle 2a was rather effective and surpassed the level of inhibition observed for the mannose-bearing cyclophanes $\mathbf{4 a}$ and $\mathbf{4 b}$ (Fig. 3E). The acyclic and more flexible derivative 1a was also active (Fig. 3D). In direct comparison at a normalized sugar concentration of $0.1 \mathrm{mM}$, the establishment of a rigid scaffold for sugar presentation consistently resulted in an increase in inhibition of ConA binding compared to the less rigid scaffold (2a more potent than 1a) (Fig. 3F). Among the terephthalamides compound $\mathbf{9}$ gave the highest level of blocking lectin binding, surpassing that of the increasingly flexible bisubstituted tetraethylene glycol 11 (Fig. 3D) and other terephthalamides $\mathbf{7}$ and $\mathbf{8}$. In order to next infer dependence on the type of lectin a respective experimental series were investigated with another leguminous lectin (Fig. 4). When using the closely related lectin Pisum sativum agglutinin as a probe, the relative 

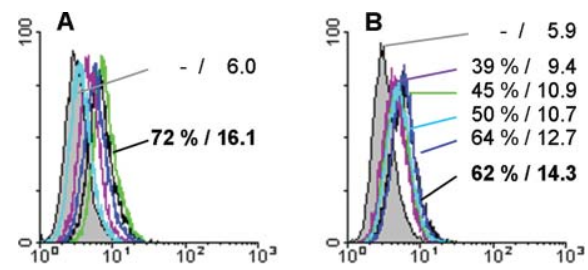

Fig. 4 Staining of cells of the human colon adenocarcinoma line SW480 by $0.2 \mu \mathrm{g} \mathrm{ml}^{-1}$ labelled Pisum sativum agglutinin (for further details, please see legend to Fig. 3). A: Inhibition of lectin binding by increasing concentrations of mannose $(0.1 \mathrm{mM}, 0.5 \mathrm{mM}, 2 \mathrm{mM}, 8 \mathrm{mM})$. B: Inhibition of lectin binding by $0.5 \mathrm{mM}$ sugar in compound $\mathbf{9}$, as free mannose, in compound $\mathbf{4 a}$ and in compound $\mathbf{8}$.

potencies did indeed not remain constant. The monomer 6a was less active than free mannose (not shown). Macrocycle 4a was a comparatively stronger inhibitor than $\mathbf{2 a}$ and also its acyclic analogue 3a, but only barely displaying the inhibitory efficiency of free mannose (Fig. 4B). Terephthalamide-based scaffolds also proved to be bioactive, with 9 being again more potent than 7 and 8, demonstrating the significant impact on linkage types (Fig. 4B). Taking these data into account it thus does not appear to be valid to extrapolate data within a lectin family. To next reveal whether the inhibitory potency on ConA will depend on the glycan profile, we performed three series of experiments.

First, we treated the colon cancer cells with mannosidase I inhibitor 1-deoxymannojirimycin to shift glycan processing from generating complex-type to high-mannose-type glycosylation and, indeed, obtained the expected increase in ConA binding (Fig. 5A). Thus, we could address the issue on the relationship of inhibitory potency to a variation in glycan display and subsequently examined each compound's activity. Overall, the respective measurements quantitatively yielded a rather similar distribution of activity when compared to assays carried out with the untreated cells. Of note, macrocycle $\mathbf{2 a}$ showed increased activity with a more than 2.5-fold difference relative to its open form 1a (please note: plots given in Fig. 5B were recorded at $0.2 \mathrm{mM}$ mannose concentration for compound $\mathbf{2 a}$ vs. $0.5 \mathrm{mM}$ for compound 1a). This result intimates again the enhanced potential of a suitable macrocyclic compound to block binding at increased cell surface ligand density. Activity grading among terephthalamide-based

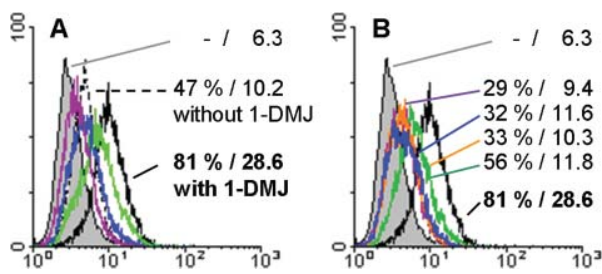

Fig. 5 Staining of cells of the human colon adenocarcinoma line SW480 after treatment with 1-deoxymannojirimicin by $1 \mu \mathrm{g} \mathrm{ml}^{-1}$ labelled ConA (for further details, please see the legend to Fig. 3). A: Staining parameters in the absence (dashed) and in the presence of 1-deoxymannojirimycin (black) as well as its inhibition by the presence of $0.5 \mathrm{mM}, 2 \mathrm{mM}$ and $10 \mathrm{mM}$ mannose, respectively. B: Inhibition of lectin binding by $0.2 \mathrm{mM}$ sugar in compound $\mathbf{2 a}, 0.5 \mathrm{mM}$ sugar in compound $\mathbf{1 a}, 0.2 \mathrm{mM}$ sugar in compound $6 \mathbf{a}$ and $0.5 \mathrm{mM}$ sugar in compound $\mathbf{8}$ compared to the following reference data when using free sugar: $62 \% / 20$ at $0.5 \mathrm{mM}$ mannose and $42 \% / 11.9$ at $2 \mathrm{mM}$ mannose. compounds remained similar, with bivalent compound $\mathbf{8}$ still proving slightly more active than free mannose (Fig. 5B).

Second, we tested a cell system from a different tumour type, using the human pancreatic carcinoma line Capan-1. Commonly, cell surface glycosylation changes among different tumour types. The bioactivity profiles of the test compounds disclosed a notable activity for terephthalamide derivative 9 and tetraethylene glycol 11 (Fig. 6). However, macrocyclic ring-closure led only to a slight improvement of the activity of compound $\mathbf{2 a}$ compared to open form 1a (Fig. 6A, B); this contrasted to that observed for the colon adenocarcinoma cells, especially after increasing high-mannosetype surface glycosylation. The open form 1a displayed a value close to that observed for the mannose reference at $22 \% / 10.5$, corroborating the concept for a dependence of relative compound activity on cell-surface characteristics.
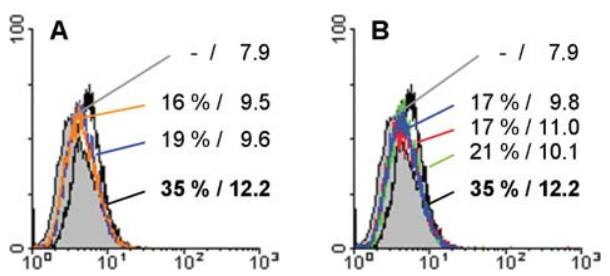

Fig. 6 Staining of cells of the human pancreatic carcinoma line Capan-1 by $1 \mu \mathrm{g} \mathrm{ml}^{-1}$ labelled ConA (for further details, please see legend to Fig. 3). A: Inhibition of lectin binding by $0.5 \mathrm{mM}$ sugar in compounds $2 \mathrm{a}$ and 9 (reference value for free mannose: $22 \% / 10.5$ ). B: Inhibition of lectin binding by $0.5 \mathrm{mM}$ sugar in compounds $\mathbf{6 a}, \mathbf{1 1}$ and $\mathbf{1 a}$ compared to staining in the absence of any inhibitor.

Besides altering the cell-type and density of ligands on a cell surface, the affinity of a lectin for a cell type can also be manipulated. A method to increasing ConA affinity for a cell involves truncation of complex-type $N$-glycans so that terminal GlcNAc moieties are found in the branches. ${ }^{6 b, c}$ We thus finally tested a glycosylation mutant of Chinese hamster ovary (CHO) cells with impaired galactosylation (Lec8). Whereas ligand density had previously appeared to alter reactivity to rigid macrocycle $\mathbf{2 a}$, the presentation of high-affinity ligands on $\mathrm{CHO}$ cells led to no significant shifts relative to that observed in assays with colon cancer cells. As noted before, the monomeric derivative 6a was active, and the inhibitory grading including the $\mathbf{2 a} / \mathbf{1} \mathbf{a}$ comparison remained rather constant, as exemplarily illustrated in Fig. 7. Terephthalamide 9 was again active. Thus for two different cell types, increasing the density of mannose residues and presenting
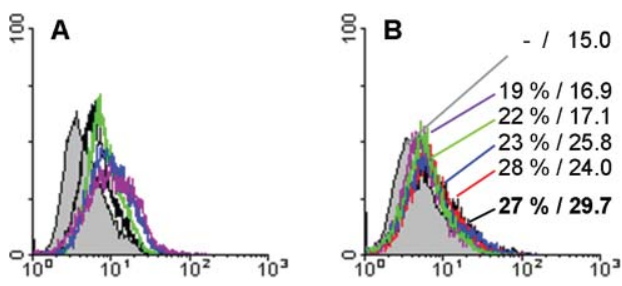

Fig. 7 Staining of cells of the Chinese hamster ovary glycosylation mutant line Lec 8 by labelled ConA (for further details, please see legend to Fig. 3). A: Staining with increasing concentrations of labelled ConA $\left(0.2 \mu \mathrm{g} \mathrm{ml}^{-1}\right.$, $0.5 \mu \mathrm{g} \mathrm{ml}^{-1}, 1 \mu \mathrm{g} \mathrm{ml}^{-1}$ and $2 \mu \mathrm{g} \mathrm{ml}^{-1}$ ). B: Inhibition of lectin binding at a concentration of $1 \mu \mathrm{g} \mathrm{ml}^{-1}$ by $0.5 \mathrm{mM}$ sugar in compounds $\mathbf{2 a}, \mathbf{9}$ and $\mathbf{1 a}$ compared to $1 \mathrm{mM}$ free mannose and the control in the absence of sugar. 
high-affinity ligands by $N$-glycan truncation were tested and the results revealed a consistent effect of both scaffold rigidity and structure on inhibitory activity. Particular rigid structures based on glycocyclophane scaffolds, as the cell based tests with the two tested leguminous lectins reveal, may selectively improve blocking of cell binding, as parallel assays with the compound pairs 1a/2a and $\mathbf{3 a} / \mathbf{4 a}$ documented. Of practical value, the outlined routes to tailor cell surface glycosylation are proposed to be of general importance for testing glycan derivatives and glycoclusters.

\section{Conclusion}

Our report addresses the question of potency in cell assays of bivalent mannosides presented on a variety of scaffolds. We specifically compared compounds based on both flexible and rigid scaffolds and also compared differing spatial arrangement of ligands presented on two subtly distinctive rigid macrocyclic scaffolds. Toward this end, we reported the facile synthesis of two types of phenylenediamine-based glycocyclophanes and improvements to preparing derivatives based on the terephthalamidebased scaffold. Bioactivity was tested in cell assays, revealing consistent lectin-binding properties of the derivatives. Obviously, macrocycles ${ }^{12}$ can serve as an effective ligand-presenting scaffold, as also documented for tetraaza[6.1.6.1]paracyclophane or also cyclic peptides as macrocyclic frameworks. ${ }^{13,14}$ Also, terephthalamide derivatives were shown to be active. Herein, we move beyond common haemagglutination, precipitation or solid-phase data to let the glycocompounds compete with cell surface glycans for lectin binding. The presented results therefore extend the available data on bivalent compounds and ConA binding, delineating an impact of intra-mannosyl distance and linkage type, e.g. obtained with diamine cores. ${ }^{15}$ The reduction of the inherent level of flexibility appeared to have a favorable impact especially for cells displaying a high ligand density, and the structure of the macrocycle can modulate inhibitory potency in interlectin comparison (ConA/PSA). In addition to conformational restraint the three-dimensional presentation of the ligands, highly dependent on the scaffold employed, could factor into differences observed in the assay system.

Of general importance beyond the nature of this model, we have set up a strategy for cell assays, which minimizes the risk for invalid generalizations and reaches high sensitivity to probe influence of the nature of glycomic profiles. It consists of two different lines and manipulations of the glycomic profile by recruiting an inhibitor for glycan processing and a glycosylation mutant. Because interference with cell binding is a medically relevant parameter and tissue lectins can target distinct ligands with context-dependent glycosylation, e.g. as recognition signals in adhesion, induction of apoptosis or glycoprotein routing, ${ }^{2,4,16}$ this approach is proposed to find applications in studies on endogenous lectins.

\section{Experimental} Allyl 2,3,4,6-tetra- $O$-acetyl- $\alpha$-D-mannopyranosyl-(1 $\rightarrow 3)-2,4$-di- $O$ -
acetyl-1- $O$-allyl- $\beta$-D-glucopyranosiduronate 14

Ester $13^{20}$ (74 mg, $\left.0.21 \mathrm{mmol}\right)$ and $15(112 \mathrm{mg}, 0.22 \mathrm{mmol})$ were dissolved in dry dichloromethane $(5 \mathrm{~mL})$ and molecular sieves were added and the mixture was stirred at room temp and under $\mathrm{N}_{2}$ for $20 \mathrm{~min}$. The mixture was then cooled on an ice bath and $0.04 \mathrm{M}$ TMSOTf in dry dichloromethane $(0.5 \mathrm{~mL}, 0.02 \mathrm{mmol})$ was then added dropwise. Stirring was continued on ice for $30 \mathrm{~min}$ and solid $\mathrm{NaHCO}_{3}(90 \mathrm{mg})$ was then added and the mixture stirred for a further $5 \mathrm{~min}$. Filtration was followed by removal of solvent under diminished pressure. Chromatography (dichloromethaneEtOAc, $5: 1)$ of the residue gave the protected disaccharide as a white solid $(107 \mathrm{mg}, 78 \%) ;[\alpha]_{\mathrm{D}}=+13.51\left(c 0.21, \mathrm{CHCl}_{3}\right) ; R_{\mathrm{f}} 0.7$ (dichloromethane-MeOH, $95: 5)$; ${ }^{1} \mathrm{H}-\mathrm{NMR}\left(\mathrm{CDCl}_{3}, 300 \mathrm{MHz}\right)$ : $\delta=6.01-5.83(\mathrm{~m}, 2 \mathrm{H}, \mathrm{CH}=), 5.43-5.09(\mathrm{~m}, 9 \mathrm{H}$, overlapping $\mathrm{H}-$ 4 GlcA, H-4 Man, $\mathrm{CH}_{2}=$, H-3 Man, H-2 Man and H-2 GlcA), 5.01 (s, 1H, H-1 Man), 4.74-4.62 (m, 2H, $\left.\mathrm{CO}_{2} \mathrm{CH}_{2}\right), 4.54$ (d, $J$ 7.5, 1H, H-1 GlcA), 4.42-4.06 (m, 5H, overlapping of $\mathrm{OCH}_{2}$, H-6, Man, H-6 ${ }_{\mathrm{b}}$ Man and H-5 Man), 4.01 (d, $J$ 9.6, 1H, H-5 GlcA), 3.96-3.90 (t, J 9.0, 1H, H-3 GlcA), 2.19 (s, 3H, $\mathrm{OCOCH}_{3}$ ), 2.16 (br s, 9H, $\mathrm{OCOCH}_{3}$ ), 2.07, 2.01 (each s, 3H, $\mathrm{OCOCH}_{3}$ ); ${ }^{13} \mathrm{C}$ NMR $\left(\mathrm{CDCl}_{3}, 75 \mathrm{MHz}\right): \delta=170.6,170.1,169.7,169.6,169.5$, 169.2, 168.8 (each CO), 133.2, 131.2 (each CH), 119.4, 117.7 (each $\mathrm{CH}_{2}$ ), 99.5 (overlapping C-1 GlcA, C-1 Man), 80.5, 72.6, 72.1, 70.2 (each $\mathrm{CH}), 69.9\left(\mathrm{OCH}_{2}\right), 69.6,69.5,68.8$ (each $\left.\mathrm{CH}\right), 66.7$ $\left(\mathrm{CO}_{2} \mathrm{CH}_{2}\right), 65.2(\mathrm{CH}), 61.8\left(\mathrm{CH}_{2}\right), 20.9,20.8,20.7,20.7,20.6$, 20.6 (each $\mathrm{CH}_{3}$ ); HRMS (ES): calcd $711.2112[\mathrm{M}+\mathrm{Na}]^{+}$, found 711.2087; IR (film from dichloromethane): 3369, 3197, 2981, 1751, $1608,1373,1224 \mathrm{~cm}^{-1}$. To the protected disaccharide $(107 \mathrm{mg}$, $0.155 \mathrm{mmol})$ in dry acetonitrile $(1 \mathrm{~mL})$ at $0{ }^{\circ} \mathrm{C} \mathrm{Pd}\left(\mathrm{Ph}_{3} \mathrm{P}\right)_{4}(18 \mathrm{mg}$, $0.015 \mathrm{mmol})$ followed by pyrrolidine $(12 \mu \mathrm{L}, 0.16 \mathrm{mmol})$ were added under $\mathrm{N}_{2}$ and the mixture was stirred at $0{ }^{\circ} \mathrm{C}$ for $25 \mathrm{~min}$ and then filtered through celite. The solvent was removed under diminished pressure and the yellow residue was dissolved in EtOAc and washed with water. The aq phase was acidified to $\mathrm{pH}=4$ with Amberlite- $\mathrm{H}^{+}$resin and then filtered. The filtrate was extracted with EtOAc $(4 \times 10 \mathrm{~mL})$ and the combined organic extracts were dried $\left(\mathrm{MgSO}_{4}\right)$, filtered and the solvent was removed to give $\mathbf{1 4}$ as a pale yellow foam $(65 \mathrm{mg}, 65 \%) ;[\alpha]_{\mathrm{D}}=+1.69\left(c 0.53, \mathrm{CHCl}_{3}\right)$; ${ }^{1} \mathrm{H}-\mathrm{NMR}\left(\mathrm{CDCl}_{3}, 300 \mathrm{MHz}\right): \delta=5.90-5.78(\mathrm{~m}, 1 \mathrm{H}, \mathrm{CH}=), 5.42$ (br s, $1 \mathrm{H}, \mathrm{CO}_{2} \mathrm{H}$ ), 5.36-5.11 (m, 6H, overlapping $\mathrm{H}-4$ GlcA, H-4 Man, $\mathrm{CH}_{2}=$, H-3 Man, H-2 Man), 5.09-5.03 (t, $J$ 7.5, 1H, H2 GlcA), 4.98 (d, $J$ 1.5, 1H, H-1 Man), 4.56 (d, $J$ 6.9, 1H, H-1 GlcA), 4.41-4.35 (dd, $J$ 4.8, 13.2, 1H, H-6 ${ }_{\mathrm{a}}$ Man), 4.26-4.21 (dd, $J$ 3.6, -12.6, 1H, H-6 $6_{\mathrm{b}} \mathrm{Man}$ ), 4.16-4.01 (m and d overlapping, $4 \mathrm{H}, J$ 9, H-5 GlcA, $\left.\mathrm{OCH}_{2}, \mathrm{H}-5 \mathrm{Man}\right), 3.96-3.90$ (t, $J$ 8.7, $1 \mathrm{H}$, H-3 GlcA), 2.15, 2.14 (each s, 3H, $\mathrm{OCOCH}_{3}$ ), 2.11 (br s, 6H, $\left.\mathrm{OCOCH}_{3}\right), 2.03,1.97$ (each s, 3H, OCOCH$\left.{ }_{3}\right) ;{ }^{13} \mathrm{C}-\mathrm{NMR}\left(\mathrm{CDCl}_{3}\right.$, $75 \mathrm{MHz}$ ): $\delta=170.9,170.1,169.8,169.3,168.8$ (each CO), 133.2 $(\mathrm{CH}), 117.8\left(\mathrm{CH}_{2}\right), 99.3(\mathrm{C}-1 \mathrm{GlcA}$ and $\mathrm{C}-1 \mathrm{Man}), 78.8(\mathrm{CH})$, $72.0(2 \mathrm{CH}), 70.1\left(\mathrm{OCH}_{2}\right), 69.9(\mathrm{CH}), 69.5(2 \mathrm{CH}), 68.8,65.3($ each CH), 61.9 (C-6 Man), 20.9, 20.8, 20.8, 20.7, 20.6, (each $\mathrm{OCOCH}_{3}$ ); HRMS (ES): calcd 647.1822 [M - H] $]^{-}$, found 647.1823; IR (film from dichloromethane): 3623, 3423, 2943, 1749, 1645, 1431, 1373, $1225 \mathrm{~cm}^{-1}$.

\section{1,4-Di-I( $N$-(1-methoxycarbonyl)methylamino-2-oxoethyl)-2,3,4,6- tetra- $O$-acetyl- $\alpha$-D-mannopyranosyl-( $\rightarrow 3)$-2,4-di- $O$-acetyl-1- $O$ - allyl- $\beta$-D-glucopyranuronamido]benzene $20 \mathrm{a}$}

Formaldehyde ( $14 \mu \mathrm{L}$ from a $37 \%$ solution in water, $0.165 \mathrm{mmol}$ ) was added to acid $14(107 \mathrm{mg}, 0.165 \mathrm{mmol})$ and 1,4phenylenediamine $(8.2 \mathrm{mg}, 0.076 \mathrm{mmol})$ in $\mathrm{MeOH}(1.5 \mathrm{~mL})$ 
at room temp and the mixture was stirred for $1 \mathrm{~h}$ and then methyl isocyanoacetate $(15 \mu \mathrm{L}, 0.17 \mathrm{mmol})$ was added and stirring continued for a further $24 \mathrm{~h}$. The solvent was evaporated to give a dark residual solid. Chromatography of the residue (EtOAc, then dichloromethane-MeOH 98:2) gave 20a as an off-white solid $(76 \mathrm{mg}, 62 \%) ;[\alpha]_{\mathrm{D}}=+13.3\left(c 0.24, \mathrm{CHCl}_{3}\right) ; R_{\mathrm{f}} 0.28$ (dichloromethane-MeOH, $95: 5)$; ${ }^{1} \mathrm{H}-\mathrm{NMR}\left(\mathrm{CDCl}_{3}, 300 \mathrm{MHz}\right)$ : $\delta=7.56$ (s, 4H, aromatic H), 6.89-6.85 (t, J 5.4, 2H, NH), 5.82$5.71(\mathrm{~m}, 2 \mathrm{H}, \mathrm{CH}=), 5.47-5.42(\mathrm{t}, J$ 9.3, 2H, H-4 GlcA), 5.335.27 (t, $J$ 10.2, 2H, H-4 Man), 5.23-5.08 (m, 8H, overlapping of $\mathrm{CH}_{2}=$, H-3 Man, H-1 Man), 4.89-4.84 (m, 4H, overlapping of H-2 Man, H-2 GlcA), 4.53-4.48 (d, $J$ 15.6, 2H, $\mathrm{CH}_{2} \mathrm{CONH}$ ), 4.28-4.14 (m, 8H, overlapping $\mathrm{H}-1$ GlcA, $\mathrm{CH}_{2} \mathrm{CONH}, \mathrm{H}-6_{\mathrm{a}} \mathrm{Man}$, $\left.\mathrm{OCH}_{2}\right)$, 4.07-3.86 (m, 10H, overlapping $\mathrm{H}-5 \mathrm{GlcA}, \mathrm{NHCH}_{2} \mathrm{CO}_{2}$, H-5 Man, H-6 ${ }_{\mathrm{b}}$ Man and $\mathrm{OCH}_{2}$ ), 3.77-3.74 (m, 2H, H-3 GlcA), $3.74\left(\mathrm{~s}, 6 \mathrm{H}, \mathrm{CO}_{2} \mathrm{CH}_{3}\right), 2.15,2.12,2.09,2.04,2.02,1.96$ (each s, 3H, $\left.\mathrm{OCOCH}_{3}\right) ;{ }^{13} \mathrm{C}-\mathrm{NMR}\left(\mathrm{CDCl}_{3}, 125 \mathrm{MHz}\right): \delta=171.3,170.8,170.2$ (2 s), 169.8, 169.7, 169.4, 168.2, 166.6 (each CO), 142.2 (aromatic C), $133.4(\mathrm{CH}), 129.4$ (aromatic $\mathrm{CH}), 117.7\left(\mathrm{CH}_{2}\right), 100.0,99.7$, 80.5, 77.4, 71.9, 71.0 (each $\mathrm{CH}), 70.1\left(\mathrm{CH}_{2}\right), 69.8,69.7,69.0,65.6$ (each $\mathrm{CH}), 62.0$ (C-6 Man), $54.6\left(\mathrm{NCH}_{2} \mathrm{CONH}\right), 52.4\left(\mathrm{CO}_{2} \mathrm{CH}_{3}\right)$, $41.3\left(\mathrm{NHCH}_{2} \mathrm{CO}_{2} \mathrm{CH}_{3}\right), 21.2,21.1,21.0$ (2 s), 20.9, 20.8 (each $\mathrm{CH}_{3}$ ); HRMS (ES): calcd 1649.5029 [M+Na] ${ }^{+}$, found 1649.4958; IR (film from dichloromethane): 3631-3374, 2966, 1751, 1670, $1510,1438,1373,1223,1040 \mathrm{~cm}^{-1}$.

\section{1,4-Di-I( $N$-(1-methoxycarbonyl)methylamino-2-oxoethyl)- $\alpha$-D- mannopyranosyl-(1 $\rightarrow$ 3)-1- $O$-allyl- $\beta$-D-glucopyranuronamido]- benzene 1a}

To a flask containing potassium cyanide $(5.4 \mathrm{mg}, 0.083 \mathrm{mmol})$, which had been pre-dried under high vacuum, a solution of $\mathbf{2 0}$ (23 mg, $0.014 \mathrm{mmol})$ in dry $\mathrm{MeOH}(3 \mathrm{~mL})$ was added under $\mathrm{N}_{2}$ and at room temp and stirring was continued for $20 \mathrm{~h}$. The solvent was removed under diminished pressure and semi-preparative HPLC of the residue (isocratic elution, $\left.\mathrm{H}_{2} \mathrm{O}-\mathrm{CH}_{3} \mathrm{CN}, 96: 4\right)$ gave $\mathbf{1 a}$ as a white solid after lyophilization $(2.8 \mathrm{mg}, 18 \%) ;{ }^{1} \mathrm{H}-\mathrm{NMR}\left(\mathrm{D}_{2} \mathrm{O}\right.$, $300 \mathrm{MHz}): \delta=7.61(\mathrm{~s}, 4 \mathrm{H}$, aromatic $\mathrm{H}), 5.98-5.92(\mathrm{~m}, 2 \mathrm{H}, \mathrm{CH}=)$, 5.39-5.29 (m, 4H, $\left.\mathrm{CH}_{2}=\right), 5.18$ (s, 2H, H-1 Man), 4.93-4.86 (d, J $\left.20.1,2 \mathrm{H}, \mathrm{NCH}_{2} \mathrm{CONH}\right), 4.72-4.65$ (d, $\left.J 20.1,2 \mathrm{H}, \mathrm{NCH}_{2} \mathrm{CONH}\right)$, $4.58-4.55$ (d, $J$ 8.1, 2H, H-1 GlcA), 4.31-4.20 (m, 2H, $\mathrm{OCH}_{2}$ ), 4.22-4.20 (d, J 8.4, 2H, H-5 GlcA), 4.11-4.09 (m, 2H, $\mathrm{OCH}_{2}$ ), 4.05 (m, 2H, H-2 Man), 4.01-3.91 (m, 4H, overlapping of $\mathrm{H}-2$ GlcA, H-5 Man), 3.87 (s, 4H, $\mathrm{NHCH}_{2} \mathrm{CO}_{2}$ ), 3.85-3.76 (m, 6H, overlapping of H-3 Man, H-6 $6_{\mathrm{a}}$ Man, H- $6_{\mathrm{b}}$ Man), 3.74-3.67 (t, $J$ 9.6, 2H, H-4 GlcA), 3.60-3.52 (m, 2H, H-3 GlcA), 3.39-3.33 (t, $J$ 8.1, 2H, H-4 Man); HRMS (ES): $[\mathrm{M}-2 \mathrm{H}]^{2-}$ calcd 546.1697, found 546.1805, LRMS (ES): $1093.5[\mathrm{M}-\mathrm{H}]^{-}$. The hydrolysis byproduct $6 \mathbf{6}$ was also obtained by HPLC (2.6 mg, 25\%); ${ }^{1} \mathrm{H}-\mathrm{NMR}$ $\left(\mathrm{D}_{2} \mathrm{O}, 300 \mathrm{MHz}\right): \delta=7.27-7.24(\mathrm{~d}, J 8.7,2 \mathrm{H}$, aromatic $\mathrm{H}), 6.79-$ $6.76(\mathrm{~d}, J 8.7,2 \mathrm{H}$, aromatic $\mathrm{H}), 6.06-5.87(\mathrm{~m}, 1 \mathrm{H}, \mathrm{CH}=), 5.38-$ $5.29\left(\mathrm{~m}, 2 \mathrm{H}, \mathrm{CH}_{2}=\right), 5.18$ (s, 1H, H-1 Man), 4.72 (s, overlapping with $\mathrm{HOD}$ signal, $\left.\mathrm{NCH}_{2} \mathrm{CONH}\right), 4.49$ (s, 2H, $\left.\mathrm{NHCH}_{2} \mathrm{CONH}\right)$, 4.32-4.26 (m, 1H, $\mathrm{OCH}_{2}$ ), 4.18-4.15 (d, $J$ 8.1, 1H, H-1 GlcA), 4.10-4.05 (m, 2H, overlapping $\mathrm{OCH}_{2}, \mathrm{H}-2 \mathrm{Man}$ ), 3.97-3.77 (m, $6 \mathrm{H}$, overlapping of H-5 GlcA, H-2 GlcA, H-5 Man, H-3 Man, H-6 a $_{\text {a }}$ H-6 $\mathrm{ban}$ ), 3.85 (s, 4H, $\mathrm{NHCH}_{2} \mathrm{CO}_{2}$ ), 3.74-3.67 (t, $J$ 9.6, 1H, H-4 GlcA), 3.50-3.56 (m, 1H, H-3 GlcA), 3.38-3.33 (t, J 8.1, 1H, H-4 Man); HRMS (ES): calcd 715.2310, found 715.2329, $[\mathrm{M}-\mathrm{H}]$. $^{-}$
1,4-Di-[( $N$-(1-methoxycarbonyl)methylamino-2-oxoethyl)- $\alpha$-Dmannopyranosyl-(1 $\rightarrow 3)$-1- $O$-allyl- $\alpha$-D-glucopyranuronamidolbenzene 3a

Deprotection of 21a (7 mg, $4.3 \mu \mathrm{mol})$ with $\mathrm{KCN}-\mathrm{MeOH}$ as described for 20a gave 3a as a white solid after lyophilization $(1.2 \mathrm{mg}$, $25 \%$ ); ${ }^{1} \mathrm{H}-\mathrm{NMR}\left(\mathrm{D}_{2} \mathrm{O}, 300 \mathrm{MHz}\right): \delta=7.61$ (s, 4H, aromatic $\mathrm{H}$ ), 5.78-5.70 (m, 2H, $\mathrm{CH}=), 5.26-5.17\left(\mathrm{~m}, 6 \mathrm{H}\right.$, overlapping of $\mathrm{CH}_{2}=$, H-1 Man), 4.96-4.95 (d, J 3.5, 2H, H-1 GlcA), 4.79-4.76 (m, $\mathrm{NCH}_{2} \mathrm{CONH}$ ), 4.55-4.53 (d, $J$ 10, 2H, $\mathrm{NCH}_{2} \mathrm{CONH}$ ), 4.31-4.29 (d, J 10, 2H, H-5 GlcA), 4.06-4.05 (m, 2H, H-2 Man), 3.97-3.92 (m, 4H, overlapping H-2 GlcA, H-5 Man), 3.88-3.74 (m, 10H, overlapping of H-3 Man, $\mathrm{NHCH}_{2} \mathrm{CO}_{2}, \mathrm{H}-6_{\mathrm{a}}$ Man, H- $6_{\mathrm{b}} \mathrm{Man}$ ), 3.73-3.64 (m, 2H, $\left.\mathrm{OCH}_{2}\right), 3.59-3.54\left(\mathrm{~m}, 2 \mathrm{H}, \mathrm{OCH}_{2}\right)$ overlapping with 3.56-3.52 (t, $J$ 9, 2H, H-4 GlcA), 3.47-3.42 (m, 2H, H3 GlcA), 3.31-3.27 (t, $J$ 9, 2H, H-4 Man); LRMS (ES): 546.3 $[\mathrm{M}-2 \mathrm{H}]^{2-}$.

\section{1,4-Di-I( $N$-(1-methoxycarbonyl)methylamino-2-oxoethyl)- $\alpha-\mathrm{D}-$ mannopyranosyl-(1 $\rightarrow 3)$-1-azido-1-deoxy- $\beta$-D- glucopyranuronamido]benzene $5 \mathbf{a}$}

The protected dimer 22 (24 mg, $0.015 \mathrm{mmol})$ was suspended in water-MeOH-NEt ${ }_{3}:(1: 1: 8,5 \mathrm{~mL})$ and the mixture stirred for $24 \mathrm{~h}$ at room temp and for a further $24 \mathrm{~h}$ at $50{ }^{\circ} \mathrm{C}$ and the solvent was then removed. Semi-preparative HPLC of the residue $(16 \mathrm{mg}$, gradient elution, $0.1 \%$ aq TFA- $\left.\mathrm{CH}_{3} \mathrm{CN}, 97: 3-50: 50\right)$ gave 5a as a white solid (1.3 mg, 8\%); ${ }^{1} \mathrm{H}-\mathrm{NMR}$ : $\left(500 \mathrm{MHz}, \mathrm{D}_{2} \mathrm{O} ; E E: E Z,{ }^{21}\right.$ $10: 1)$ : peaks for the $E E$ isomer: $\delta 7.59$ (s, $4 \mathrm{H}, \mathrm{Ar}-H), 5.16(\mathrm{~d}, J$ 1.2, 2H, H-1 Man), 4.57 (s, 4H, $\left.\mathrm{NCH}_{2} \mathrm{CONHCH}_{2}\right), 4.51$ (d, $J 8.8$, 2H, H-1 GlcA), 4.13 (d, $J$ 9.7, 2H, H-5 GlcA), 4.03 (dd, $J$ 3.2, 1.7, 2H, H-2 Man), 3.95 (t, $J$ 9.4, 2H, H-4 GlcA), 3.91 (ddd, $J$ 10.0, 4.8, 2.4, 2H, H-5 Man), 3.85 (s, 4H, $\mathrm{NCH}_{2} \mathrm{CONHCH}_{2}$ ), 3.85-3.73 $(\mathrm{m}, 6 \mathrm{H}), 3.80(\mathrm{dd}, J=12.3,2.3,2 \mathrm{H}), 3.75(\mathrm{dd}, J=12.3,4.9,2 \mathrm{H})$, $3.70(\mathrm{t}, J=9.9,2 \mathrm{H}), 3.57(\mathrm{t}, J=9.1,2 \mathrm{H}, \mathrm{H}-3 \mathrm{GlcA}), 3.33(\mathrm{t}, J=$ 9.0, 2H, H-2 GlcA); LRMS (ES): $1063.0[\mathrm{M}-\mathrm{H}]^{-}, 531.0[\mathrm{M}-$ $2 \mathrm{H}]^{2-}$; HRMS (ES): calcd $531.1449[\mathrm{M}-2 \mathrm{H}]^{2-}$, found 531.1468. Selected ${ }^{1} \mathrm{H}-\mathrm{NMR}$ data for the $E Z$ isomer: $\delta 7.54(\mathrm{~d}, J=8.64 \mathrm{~Hz}$, 2H), 7.45 (d, $J=8.7 \mathrm{~Hz}, 2 \mathrm{H}), 5.28(\mathrm{~s}, 1 \mathrm{H}), 4.95$ (d, $J=8.4 \mathrm{~Hz}$, $1 \mathrm{H}), 3.44(\mathrm{t}, J=8.8 \mathrm{~Hz}, 1 \mathrm{H})$.

\section{Glycocyclophane 2a}

A degassed solution of the diamide 20a (47 mg, 0. $029 \mathrm{mmol})$ in dry dichloromethane $(17 \mathrm{~mL}, 1.7 \mathrm{mM})$ and under $\mathrm{N}_{2}$ was treated with Grubbs-I catalyst $(5.2 \mathrm{mg}, \sim 10 \%)$ for $60 \mathrm{~h}$. The solvent was evaporated under diminished pressure and gave a black residue. Chromatography (dichloromethane-MeOH $97: 3$ ) gave the macrocyclic product as an inseparable $2: 3$ mixture of $c i s$ and trans isomers $(42 \mathrm{mg}, 91 \%) ; R_{\mathrm{f}} 0.15$ (dichloromethane-MeOH, $95: 5) ;{ }^{1} \mathrm{H}-\mathrm{NMR}\left(\mathrm{CDCl}_{3}, 300 \mathrm{MHz}\right): \delta=7.61$ (s, $4 \mathrm{H}$, aromatic $\mathrm{H}), 7.56(\mathrm{~s}, 4 \mathrm{H}$, aromatic $\mathrm{H}), 6.85-6.82(\mathrm{~m}, 2 \mathrm{H}, \mathrm{NH}), 5.74-5.70$ $(\mathrm{t}, 2 \mathrm{H}, \mathrm{J} 5.7,2 \mathrm{H}$, alkene $\mathrm{CH})$ and $5.64(\mathrm{br} \mathrm{s}, 2 \mathrm{H}$, alkene $\mathrm{CH}], 5.46-$ 5.29 (m, 4H, overlapping of H-4 GlcA and H-4 Man), 5.18-5.16 (dd J 2.7, 6, 2H, H-3Man), 5.13 (bs, 4H, overlapping of H-1 Man and H-2 Man), 4.89-4.81 (br m, 2H, H-2 GlcA), 4.78-4.72 (m, 2H, $\mathrm{OCH}_{2}$ ), 4.32 (br s, 4H, overlapping of H-6 Man), 4.22-3.87 (m, $18 \mathrm{H}$, overlapping of $\mathrm{H}-1 \mathrm{GlcA}, \mathrm{NCH}_{2} \mathrm{CO}, \mathrm{OCH}_{2}, \mathrm{NHCH}_{2} \mathrm{CO}$, H-5 GlcA, H-5 Man, H-3 GlcA), 3.75 (s, 6H, $\mathrm{CO}_{2} \mathrm{CH}_{3}$ ), 2.20, 2.18, 2.11, 2.08, 2.05, 2.01 (each s, 3H, $\mathrm{CO}_{2} \mathrm{CH}_{3}$ ), 2.19, 2.17, 
2.12, 2.09, 2.03, 1.96 (each s, $\left.3 \mathrm{H}, \mathrm{CO}_{2} \mathrm{CH}_{3}\right) ;{ }^{13} \mathrm{C}-\mathrm{NMR}\left(\mathrm{CDCl}_{3}\right.$, $125 \mathrm{MHz}): \delta=170.5,170.4,170.0,169.6(2 \mathrm{~s}), 169.5,169.1,167.8$, 166.5, 166.4 (each CO), 141.9 (aromatic C), $131.0(\mathrm{CH}=)$ ), 129.0, 128.6 (each aromatic $\mathrm{CH}), 100.0,99.7,99.4,92.2$ (C-1 GlcA and Man), 80.4, 72.4, 71.7, 71.5, 71.2, 69.9, 69.5, 69.4, 69.0, 68.9, 68.7, 68.6, 67.7, 66.2, 65.3, 65.2 (C-2 to C-5 GlcA and Man), 63.9, $62.6\left(\right.$ each $\left.\mathrm{OCH}_{2}\right), 61.6,61.5$ (each C-6 Man), $55.2\left(\mathrm{NCH}_{2} \mathrm{CO}\right)$, $52.3\left(\mathrm{CO}_{2} \mathrm{CH}_{3}\right), 41.1\left(\mathrm{NHCH}_{2} \mathrm{CO}_{2}\right), 20.9(2 \mathrm{~s}), 20.8(2 \mathrm{~s}), 20.7$ (2 s), 20.6 (each $\left.\mathrm{COCH}_{3}\right)$; HRMS (ES): $[\mathrm{M}+\mathrm{Na}]^{+}$calcd 1621.4716 found 1621.4768; IR (film from dichloromethane): 3622-3401, $2963,1750,1660,1373,1225,1041 \mathrm{~cm}^{-1}$. To this mixture $(40 \mathrm{mg}$, $0.014 \mathrm{mmol})$ in EtOAc $(2 \mathrm{~mL}), 10 \% \mathrm{Pd}-\mathrm{C}(6 \mathrm{mg})$ was added and the reaction mixture was stirred at room temp under $\mathrm{H}_{2}$. The mixture was then filtered through celite and the solvent removed under diminished pressure. Chromatography (dichloromethane$\mathrm{MeOH}, 97: 3$ ) gave the protected glycophane ( $37 \mathrm{mg}, 92 \%) ; R_{\mathrm{f}} 0.17$ (dichloromethane-MeOH, 95:5); $[\alpha]_{\mathrm{D}}=+38.7\left(c 0.23, \mathrm{CHCl}_{3}\right)$; ${ }^{1} \mathrm{H}-\mathrm{NMR}\left(\mathrm{CDCl}_{3}, 300 \mathrm{MHz}\right): \delta=7.63(\mathrm{br} \mathrm{s}, 4 \mathrm{H}$, aromatic $\mathrm{H}), 6.82$ (br s, $2 \mathrm{H}, \mathrm{NH}$ ), 5.40-5.32 (overlapping signals of $\mathrm{H}-4 \mathrm{GlcA}$ and H-4 Man) 5.22-5.15 (4H, overlapping signals of H-3 Man and H-1 Man), 4.95 (s, 2H, H-2 Man), 4.31 (br s, 4H, $\mathrm{NCH}_{2} \mathrm{CO}$ ), 4.16-4.13 (dd, J 3.7, 5.5, 2H, H-2 GlcA), 4.09-3.99 (br m, 16H, overlapping signals of $\mathrm{H}-6_{\mathrm{a}}$ Man, $\mathrm{H}-6_{\mathrm{b}}$ Man, $\mathrm{NHCH}_{2} \mathrm{CO}, \mathrm{H}-1$ GlcA, H-5 Man, H-5 GlcA, H-3 GlcA), 3.84-3.75 (m, 2H, $\left.\mathrm{OCH}_{2}\right), 3.77$ (s, $6 \mathrm{H}$, $\left.\mathrm{CO}_{2} \mathrm{CH}_{3}\right), 3.62-3.59\left(\mathrm{~m}, 2 \mathrm{H}, \mathrm{OCH}_{2}\right), 2.20,2.14,2.10,2.06,2.04$, 1.98 (each s, $\left.3 \mathrm{H}, \mathrm{CO}_{2} \mathrm{CH}_{3}\right), 1.62$ (m. $\left.4 \mathrm{H}, \mathrm{CH}_{2}\right) ;{ }^{13} \mathrm{C}-\mathrm{NMR}\left(\mathrm{CDCl}_{3}\right.$, $75 \mathrm{MHz}$ ): $\delta=170.6,170.1$ (2 s), 169.9, 169.7, 169.0, 167.8, 166.4 (each CO), 142.6 (broad signal, aromatic C), 130.2, 129.8 (broad signals, each aromatic $\mathrm{CH}$ ), 100.8, 99.9 (C-1 GlcA and Man), 80.9, 77.7, 69.6, 69.57, 69.5, 69.4, 69.0, 65.2 (2 s) (C-2-C-5 GlcA and Man, $\left.\mathrm{OCH}_{2}\right), 61.5(\mathrm{C}-6 \mathrm{Man}), 52.3\left(\mathrm{NCH}_{2} \mathrm{CO}\right), 52.3\left(\mathrm{CO}_{2} \mathrm{CH}_{3}\right)$, $41.1\left(\mathrm{NHCH}_{2} \mathrm{CO}_{2}\right), 20.9,20.8(2 \mathrm{~s}), 20.7$ (2 s), $20.6\left(\right.$ each $\left.\mathrm{COCH}_{3}\right)$; IR (film from dichloromethane): 3613-3405, 2959, 1748, 1655, $1509,1437,1373,1259,1223,1039 \mathrm{~cm}^{-1}$. Deprotection of this intermediate (32 mg, $0.02 \mathrm{mmol}$ ) with $\mathrm{KCN}$ and $\mathrm{MeOH}$-water $(1: 1)$ as described above for $\mathbf{1 a}$ and subsequent semi-preparative HPLC (isocratic elution, water- $\mathrm{CH}_{3} \mathrm{CN}, 99: 1$ ) and lyophilisation gave 2a (2.3 mg, $11 \%$ ); ${ }^{1} \mathrm{H}-\mathrm{NMR}\left(\mathrm{D}_{2} \mathrm{O}, 500 \mathrm{MHz}\right): \delta=7.67$ (s, $4 \mathrm{H}$, aromatic $\mathrm{H}), 5.26(\mathrm{~s}, 2 \mathrm{H}, \mathrm{H}-1 \mathrm{Man}), 4.80\left(\mathrm{~s}, 2 \mathrm{H}, \mathrm{NCH}_{2} \mathrm{CONH}\right)$, 4.65 (s, $2 \mathrm{H}, \mathrm{NCH}_{2} \mathrm{CONH}$ ), 4.44-4.43 (d, $J$ 8, 2H, H-1 GlcA), 4.12-4.05 (m, 6H, overlapping of $\left.\mathrm{H}-2 \mathrm{GlcA}, \mathrm{OCH}_{2}, \mathrm{H}-2 \mathrm{Man}\right)$, 4.02-3.99 (m, 4H, overlapping $\mathrm{H}-5$ GlcA, $\left.\mathrm{OCH}_{2}\right), 3.96(\mathrm{~s}, 4 \mathrm{H}$, $\mathrm{NHCH}_{2} \mathrm{CO}_{2}$ ) 3.94-3.91 (dd, $J 3, J 10,2 \mathrm{H}, \mathrm{H}-6 \mathrm{Man}$ ) overlapping with 3.90-3.92 (m, 2H, H-5 Man), 3.88 (d, $J$ 2, 2H, H-3 Man), 3.85-3.81 (dd, $J$ 5, 12.5, 2H, H-6 Man), 3.79-3.75 (t, $J$ 10, 2H, H-4 GlcA), 3.64-3.60 (t, $J$ 8.5, 2H, H-3 GlcA), 3.36-3.34 (t, $J$ 8, 2H, H-4 Man), 1.90-1.83 (m, 4H, $\mathrm{CH}_{2} \mathrm{CH}_{2}$ ); HRMS (ES): calcd $533.1619[\mathrm{M}-2 \mathrm{H}]^{2-}$, found 533.1617.

\section{Glycocyclophane 4a}

Ring closing metathesis of the diamide $21 \mathrm{a}(45 \mathrm{mg}, 0.027 \mathrm{mmol}$ ) as described for 20a gave a mixture of cis and trans isomers of the macrocyclic product, which was an off-white solid (32 mg, 74\%); $R_{\mathrm{f}} 0.42$ (dichloromethane-MeOH, 90:10); HRMS (ES): calcd 1621.4716 [M+Na] $]^{+}$found 1621.4757. Catalytic hydrogenation of this mixture using $10 \% \mathrm{Pd}-\mathrm{C}$ gave the protected glycophane as a white solid (24 mg, $88 \%$ ); $R_{\mathrm{f}} 0.2$ (dichloromethane- $\mathrm{MeOH}$, $95: 5) ;[\alpha]_{\mathrm{D}}=-17.1\left(c 0.18, \mathrm{CHCl}_{3}\right) ;{ }^{1} \mathrm{H}-\mathrm{NMR}\left(\mathrm{CDCl}_{3}, 500 \mathrm{MHz}\right)$ : $\delta=7.49(\mathrm{~s}, 4 \mathrm{H}$, aromatic H), 6.59-6.57 (t, $J 5.0,2 \mathrm{H}, \mathrm{NH}), 5.63-$ 5.59 (t, $J$ 9.5, 2H, H-4 GlcA), 5.30-5.26 (t, $J 10,2 \mathrm{H}, \mathrm{H}-4 \mathrm{Man}$ ), 5.19-5.17 (dd, $J$ 3, 10, 2H, H-3 Man), 5.10 (s, 2H, H-2 Man), 5.02 (s, 2H, H-1 Man), 5.01-5.00 (d, J 3.5, 2H, H-1 GlcA), 4.894.86 (dd, $J$ 3.0, 9.5, 2H, H-2 GlcA), 4.67-4.65 (d, $J 10,2 \mathrm{H}, \mathrm{H}-5$ GlcA), 4.50-4.47 (d, $J-15.5,2 \mathrm{H}, \mathrm{NCH}_{2} \mathrm{CONH}$ ), 4.22-4.19 (d, $\left.J-15.5,2 \mathrm{H}, \mathrm{NCH}_{2} \mathrm{CONH}\right), 4.18-4.10(\mathrm{~m}, 8 \mathrm{H}$, overlapping of H-5 Man, H-6 $6_{\mathrm{a}}$ Man, $\mathrm{H6}_{\mathrm{b}}$ Man, and H-3 GlcA), 4.03-4.01 (t, $J$ 9, 4H, $\mathrm{NHCH}_{2} \mathrm{CO}$ ), 3.77 (s, $6 \mathrm{H}, \mathrm{CO}_{2} \mathrm{CH}_{3}$ ), 3.42-3.39 (br t, $J$ $\left.-7.5,2 \mathrm{H}, \mathrm{OCH}_{2}\right), 3.31-3.29\left(\mathrm{~m} 2 \mathrm{H}, \mathrm{OCH}_{2}\right), 2.26,2.14,2.08,2.05$, 2.03, 1.98 (each s, $\left.3 \mathrm{H}, \mathrm{OCOCH}_{3}\right), 1.52-1.50\left(\mathrm{~m} 2 \mathrm{H}, \mathrm{OCH}_{2} \mathrm{CH}_{2}\right)$, $1.00-0.98\left(\mathrm{~m} 2 \mathrm{H}, \mathrm{OCH}_{2} \mathrm{CH}_{2}\right) \cdot{ }^{13} \mathrm{C}-\mathrm{NMR}\left(\mathrm{CDCl}_{3}, 125 \mathrm{MHz}\right): \delta=$ $170.6,170.0,169.9,170.1,169.8,169.7,169.5,169.1,167.5,164.5$ (each CO), 141.8 (aromatic C), 129.0 (aromatic CH), 98.2 (C-1 Man), 95.7 (C-1 GlcA), 76.3, 72.1, 71.2, 69.8, 69.4, 68.7 (each $\mathrm{CH}), 66.5\left(\mathrm{OCH}_{2}\right), 65.7,65.3$ (each $\left.\mathrm{CH}\right), 62.2$ (C-6 Man), 55.1 $\left(\mathrm{NCH}_{2} \mathrm{CO}\right), 52.4\left(\mathrm{CO}_{2} \mathrm{CH}_{3}\right), 41.2\left(\mathrm{NHCH}_{2} \mathrm{CO}_{2}\right), 26.4\left(\mathrm{t}, \mathrm{CH}_{2}\right)$, 20.9 (2 s), 20.8, 20.7, 20.6 (each $\mathrm{OCOCH}_{3}$ ); HRMS (ES): calcd $1623.4873\left[\mathrm{M}+\mathrm{Na}^{+}\right.$, found 1623.4906. Deprotection using $\mathrm{KCN}-$ $\mathrm{MeOH}$ as described for $\mathbf{1 a}$ gave the title compound $\mathbf{4 a}$ after semipreparative HPLC (isocratic elution, $0.1 \%$ aq TFA- $\mathrm{CH}_{3} \mathrm{CN}$ ) and lyophilization (1.8 mg, $15 \%) ;{ }^{1} \mathrm{H}-\mathrm{NMR}\left(\mathrm{D}_{2} \mathrm{O}, 500 \mathrm{MHz}\right): \delta=7.69$ (s, $4 \mathrm{H}$, aromatic $\mathrm{H}), 5.33$ (s, $2 \mathrm{H}, \mathrm{H}-1 \mathrm{Man}), 4.96(\mathrm{~d}, J 3.0,2 \mathrm{H}, \mathrm{H}-1$ GlcA), 4.50-4.46 (m, $\left.\mathrm{NCH}_{2} \mathrm{CONH}\right), 4.22\left(\mathrm{~m}, 2 \mathrm{H}, \mathrm{NHCH}_{2} \mathrm{CO}_{2}\right.$ ), 4.19-4.10 (4H, overlapping $\left.\mathrm{OCH}_{2}, \mathrm{H}-5 \mathrm{GlcA}\right), 4.04-4.01(\mathrm{~m}, 2 \mathrm{H}$, H-2 Man), 3.98-3.91 (m, 6H, overlapping H-5 Man, H-6 Man, H2 GlcA), 3.87-3.80 (m, $6 \mathrm{H}$, overlapping $\mathrm{OCH}_{2}$, H-3 Man), 3.783.74 (m, 4H, H-6 6 ban, H-4 GlcA), 3.50-3.46 (m, 4H, overlapping H-3 GlcA, H-4 Man), 1.61 (br m, 2H, $\mathrm{CH}_{2} \mathrm{CH}_{2}$ ), 1.02 (br m, $2 \mathrm{H}, \mathrm{CH}_{2} \mathrm{CH}_{2}$ ); HRMS (ES): calcd $533.1619[\mathrm{M}-2 \mathrm{H}]^{2-}$, found 533.1627.

\section{Glycocyclophane 4b}

Ring closing metathesis of $\mathbf{2 1 b}$ ( $97 \mathrm{mg}, 0.06 \mathrm{mmol}$ ) as described for 20a gave a mixture of cis and trans isomers of the macrocyclic product as an off-white solid (67 mg 71\%); $R_{\mathrm{f}} 0.3$ (dichloromethaneEtOAc $1: 4) ;{ }^{13} \mathrm{C}-\mathrm{NMR}\left(\mathrm{CDCl}_{3}, 75 \mathrm{MHz}\right): \delta=170.6,169.9,169.8$, 169.6, 169.5, 169.4, 167.2 (each CO), 141.9 (aromatic C), 128.4 (aromatic CH), 125.4 (alkene CH), 98.1, 96.8, 94.1 (C-1 GlcA and Man), 75.5, 71.9, 71.6, 69.7, 69.2, 68.6, 66.1, 65.8, (C-2-C-5 GlcA and Man), 65.0, $\left(\mathrm{OCH}_{2}\right), 62.1$ (C-6 Man), $55.5\left(\mathrm{NCH}_{2} \mathrm{CO}\right), 39.4$ $\left(\mathrm{NHCH}_{2}\right), 31.4\left(\mathrm{CH}_{2} \mathrm{CH}_{2}\right), 20.9,20.8,20.7,20.6\left(\right.$ each $\left.\mathrm{COCH}_{3}\right)$, $20.0\left(\mathrm{CH}_{2} \mathrm{CH}_{3}\right), 13.7\left(\mathrm{CH}_{2} \mathrm{CH}_{3}\right)$. Catalytic hydrogenation of this mixture ( $45 \mathrm{mg}, 0.028 \mathrm{mmol}$ ) using $10 \% \mathrm{Pd}-\mathrm{C}$ gave the reduced protected glycocyclophane intermediate as a white solid $(44 \mathrm{mg}$, $95 \%$ ); $R_{\mathrm{f}} 0.32$ (dichloromethane-EtOAc, $\left.1: 4\right) ;[\alpha]_{\mathrm{D}}=-18.2(c$ $\left.0.11, \mathrm{CHCl}_{3}\right) ;{ }^{1} \mathrm{H}-\mathrm{NMR}\left(\mathrm{CDCl}_{3}, 600 \mathrm{MHz}\right): \delta=7.47(\mathrm{~s}, 4 \mathrm{H}$, aromatic $\mathrm{H}), 6.11-6.09(\mathrm{t}, J 6,2 \mathrm{H}, \mathrm{NH}), 5.63-5.60$ (t, $J 9.6$, 2H, H-4 GlcA), 5.30-5.27 (t, $J$ 10.2, 2H, H-4 Man), 5.19-5.17 (dd, $J$ 3.6, 10.2, 2H, H-3 Man), 5.10-5.09 (t, $J 2.4,2 \mathrm{H}, \mathrm{H}-2$ Man), 5.02 (d, $J 1.8,2 \mathrm{H}, \mathrm{H}-1 \mathrm{Man}$ ), 4.99-4.98 (d, $J$ 3.6, 2H, H-1 GlcA), 4.89-4.87 (dd, $J$ 3.6, 10.2, 2H, H-2 GlcA), 4.674.65 (d, $J$ 9.6, 2H, H-5 GlcA), 4.30-4.27 (d, J-15, 2H, $\mathrm{NCH}_{2} \mathrm{CO}$ ), 4.19-4.17 (m, 4H, overlapping $\left.\mathrm{NCH}_{2} \mathrm{CO}, \mathrm{H}-6_{\mathrm{a}} \mathrm{Man}\right), 4,14-4.09$ (m, 6H, overlapping H-6 Man, H-5 Man, H-3 GlcA), 3.39-3.38 $\left(\mathrm{t}, J 7.8,2 \mathrm{H}, \mathrm{OCH}_{2}\right), 3.28-3.19\left(\mathrm{~m}, 6 \mathrm{H}\right.$, overlapping $\mathrm{OCH}_{2}$, $\mathrm{NCH}_{2}$ ), 2.26, 2.14, 2.08, 2.05, 2.03, 1.98 (each s, $3 \mathrm{H}, \mathrm{OCOCH}_{3}$ ), $1.51-1.46\left(\mathrm{~m}, 6 \mathrm{H}\right.$, overlapping $\left.\mathrm{OCH}_{2} \mathrm{CH}_{2}, \mathrm{CH}_{2} \mathrm{CH}_{2}\right), 1.37-1.33$ 
(q, $J$ 7.8, 4H, $\left.\mathrm{CH}_{2} \mathrm{CH}_{3}\right), 1.01-0.97\left(\mathrm{~m}, 2 \mathrm{H}, \mathrm{OCH}_{2} \mathrm{CH}_{2}\right), 0.95-$ $0.91\left(\mathrm{~m}, 6 \mathrm{H}, \mathrm{CH}_{2} \mathrm{CH}_{3}\right) ;{ }^{13} \mathrm{C}-\mathrm{NMR}\left(\mathrm{CDCl}_{3}, 150 \mathrm{MHz}\right): \delta=170.6$, 170.0, 169.8, 169.7, 169.5, 168.9, 167.4, 167.3 (each CO), 141.9 (aromatic C), 128.8 (aromatic CH), 98.2 (C-1 Man), 95.6 (C-1 GlcA), 76.3, 72.2, 71.2, 69.8, 69.4, 68.8 (each $\mathrm{CH}), 66.4\left(\mathrm{OCH}_{2}\right)$, 65.8, 65.2 (each $\mathrm{CH}), 62.2$ (C-6 Man), $55.6\left(\mathrm{NCH}_{2} \mathrm{CO}\right), 39.5$ $\left(\mathrm{NHCH}_{2}\right), 31.4\left(\mathrm{CH}_{2}\right), 26.4\left(\mathrm{OCH}_{2} \mathrm{CH}_{2}\right), 20.9,20.8(2 \mathrm{~s}), 20.7,20.6$ (each $\left.\mathrm{OCOCH}_{3}\right), 20.0\left(\mathrm{CH}_{2} \mathrm{CH}_{3}\right), 13.7\left(\mathrm{CH}_{2} \mathrm{CH}_{3}\right)$; HRMS (ES): calcd 1591.5804 $[\mathrm{M}+\mathrm{Na}]^{+}$, found 1591.5857. A solution of this protected glycophane ( $44 \mathrm{mg}, 0.028 \mathrm{mmol})$ in a mixture of $\mathrm{MeOH}-$ water- $\mathrm{NEt}_{3}(8: 1: 1,2 \mathrm{~mL})$ was stirred $50{ }^{\circ} \mathrm{C}$ for $30 \mathrm{~min}$ and then allowed to attain room temperature and stirring was continued for another $40 \mathrm{~h}$. The solvent was evaporated under reduced pressure and subsequent semi-preparative HPLC (gradient elution: $\mathrm{H}_{2} \mathrm{O}$ $\mathrm{CH}_{3} \mathrm{CN}, 99: 1$ to $\left.96: 4\right)$ and lyophilisation gave $\mathbf{4 b}$ as a white solid after lyophilization $(8.7 \mathrm{mg}, 30 \%) ;{ }^{1} \mathrm{H}-\mathrm{NMR}\left(\mathrm{D}_{2} \mathrm{O}, 500 \mathrm{MHz}\right): \delta=$ 7.62 (s, 4H, aromatic H), 5.27 (s, 2H, H-1 Man), 4.90-4.88 (d, $J$ 3. $2 \mathrm{H}, \mathrm{H}-1 \mathrm{GlcA}), 4.73-4.64\left(\mathrm{~m}, 2 \mathrm{H}, \mathrm{NCH}_{2} \mathrm{CONH}\right)$, overlapping 4.64-4.61 (d, $J$ 9.6, 2H, H-5 GlcA), 4.24-4.18 (d, $J$ 15.9, 2H, $\mathrm{NCH}_{2} \mathrm{CONH}$ ), 4.10-4.04 (m, 4H, overlapping $\mathrm{H}-2 \mathrm{Man}, \mathrm{OCH}_{2}$ ), 3.99-3.60 (m, 14H, overlapping $\mathrm{OCH}_{2}, \mathrm{H}-2$ GlcA, H-5 Man, H-3 Man, H-6 a Man, H-6 ban, H-4 GlcA) 3.44-3.36 (m, 4H, overlapping H-3 GlcA, H-4 Man), 3.17-3.12 (m, 4H, $\mathrm{NHCH}_{2}$ ), 1.56-1.50 (m, 2H, CH $\mathrm{CH}_{2}$ ), 1.40-1.34 (m, 4H, $\left.\mathrm{CH}_{2} \mathrm{CH}_{2}\right), 1.25-$ $1.18\left(\mathrm{~m}, 4 \mathrm{H}, \mathrm{CH}_{2} \mathrm{CH}_{3}\right), 0.98-0.90\left(\mathrm{~m}, 2 \mathrm{H}, \mathrm{CH}_{2} \mathrm{CH}_{2}\right), 0.87-0.83$ (t, $J$ 7.5, 6H, $\mathrm{CH}_{2} \mathrm{CH}_{3}$ ); HRMS (ES): $[\mathrm{M}-\mathrm{H}]^{-}$calcd 1063.4472, found 1063.4431: calcd 1087.4434 [M+Na] $]^{+}$, found 1087.4475.

$N, N^{\prime}$-Di-( $\alpha$-D-mannopyranosyl- $(1 \rightarrow 3)$ - $\beta$-D-glucopyranosyl)terephthalamide $\mathbf{7 b}$. A solution of amine $25(75.8 \mathrm{mg}$, $0.1193 \mathrm{mmol})$ and DIPEA $(26.4 \mu \mathrm{L}, 0.1551 \mathrm{mmol})$ in THF (anhydrous, $2 \mathrm{~mL}$ ) was added dropwise at room temp to fresh terephthaloyl chloride $(12 \mathrm{mg}, 0.059 \mathrm{mmol})$ in THF (anhydrous, $2 \mathrm{~mL}$ ). After $1 \mathrm{~h}$ the reaction was complete by TLC after which the solvent was removed. Chromatography (EtOAc-cyclohexane gradient elution, $1: 1$ to $1.5: 1$ and EtOAc- $\left.\mathrm{CH}_{2} \mathrm{Cl}_{2}, 9: 1\right)$ gave the protected terephthalamide dimer as a white amorphous solid (70 mg, 84\%); $R_{\mathrm{f}}$ 0.5, (EtOAc: $\mathrm{CH}_{2} \mathrm{Cl}_{2}, 9: 1$ ); $[\alpha]_{\mathrm{D}}+8.0$ (c 0.15, $\left.\mathrm{CHCl}_{3}\right) ;{ }^{1} \mathrm{H} \mathrm{NMR}\left(600 \mathrm{MHz}, \mathrm{CDCl}_{3}\right.$, mixture of anomers, $\beta \beta: \alpha \beta$, $83: 17)$ peaks for the major $\beta \beta$ anomer: $\delta 7.83(\mathrm{~s}, 4 \mathrm{H}$, aromatic $\mathrm{H})$ $7.06(\mathrm{~d}, J 9.0,2 \mathrm{H}, \mathrm{N} H), 5.33(\mathrm{t}, J 9.3,2 \mathrm{H}, \mathrm{H}-1 \mathrm{Glc}), 5.30(\mathrm{t}, J 10.2$, 2H, H-4 Man), 5.21 (t, $J$ 9.7, 2H, H-4 Glc), 5.16 (dd, $J$ 10.1, 3.3, 2H, H-3 Man), 5.11 (dd, $J=3.2,2.2,2 \mathrm{H}, \mathrm{H}-2$ Man), 5.04-5.00 (m, 4H, overlapping H-1 Man, H-2 Glc), 4.30 (dd, $J=12.6,4.4$, 2H, H-6b Glc), 4.19 (dd, $J=12.4,4.6,2 \mathrm{H}, \mathrm{H}-6 \mathrm{a}$ Man), 4.14-4.04 (m, 6H, overlapping H-6b Man, H-6a Glc, H-5 Man), 4.04 (t, $J=$ 9.4, 2H, H-3 Glc), 3.80 (ddd, $J$ 10.1, 4.3, 2.3, 2H, H-5 Glc), 2.17, 2.16, 2.12, 2.09, 2.09, 2.04, 1.98 (each s, 6H, $\mathrm{COCH}_{3}$ ); selected NMR data for the $\alpha \beta$ anomer: $\delta 7.92(\mathrm{~d}, J 8.37,2 \mathrm{H}$, aromatic$\mathrm{H}), 7.86(\mathrm{~d}, J 8.5,2 \mathrm{H}$, aromatic $\mathrm{H}), 7.11(\mathrm{~d}, J 9.11,1 \mathrm{H}, \mathrm{NH})$, 6.07-6.01 (m, 1H), 5.85-5.78 (m, 1H), $4.97(\mathrm{~d}, J 1.6,1 \mathrm{H}), 4.94$ $4.91(\mathrm{~m}, 1 \mathrm{H}), 4.89(\mathrm{t}, J$ 9.4, $1 \mathrm{H}) ;{ }^{13} \mathrm{C}-\mathrm{NMR}\left(150 \mathrm{MHz}, \mathrm{CDCl}_{3}\right)$ : $\delta$ 172.0, 171.0, 170.9, 170.3, 170.0, 169.9 (2 s), (each $\left.\mathrm{COCH}_{3}\right)$, $166.5(\mathrm{NHCO}), 136.5(\mathrm{C}), 128.0(\mathrm{CH}), 99.2(\mathrm{CH}) 80.7(\mathrm{CH}), 79.2$ (C-1 Glc), 74.1, 72.7, 70.1, 69.7, 69.0, 68.8, 65.7 (each $\mathrm{CH}), 62.3$ $\left(\mathrm{CH}_{2}\right), 61.9\left(\mathrm{CH}_{2}\right), 21.2,21.1,21.0$ (2 s), 20.9 (each $\left.\mathrm{COCH}_{3}\right)$; HRMS (ES): anal. calcd 1423.4075 [M+Na] $]^{+}$, found 1423.4089; IR (KBr): 3620-3361, 1759, 1678, 1544, 1375, 1227, $1042 \mathrm{~cm}^{-1}$. Zemplén deacetylation of this intermediate $(70 \mathrm{mg}, 0.05 \mathrm{mmol})$ gave a white powder $(37 \mathrm{mg}, 92 \%)$ which was as a mixture of $7 \mathbf{d}$ and 26, $85: 15$ ). Semi-preparative HPLC (isocratic elution, $\mathrm{H}_{2} \mathrm{O}$ $\left.\mathrm{CH}_{3} \mathrm{CN}, 99: 1\right)$ gave $7 \mathbf{d} ;{ }^{1} \mathrm{H}$ NMR $\left(600 \mathrm{MHz}, \mathrm{D}_{2} \mathrm{O}\right): \delta 7.93(\mathrm{~s}, 4 \mathrm{H}$, aromatic $\mathrm{H}), 5.29$ (d, $J$ 1.2, 2H, H-1 Man), 5.23 (d, $J$ 9.3, 2H, H-1 Glc), 4.08 (dd, $J$ 3.2, 1.8, 2H, H-2 Man), 3.99 (ddd, $J$ 9.9, 5.0, 2.3, 2H, H-5 Man), 3.93-3.83 (m, 6H, overlapping H-6b Glc H-3 Man, H-6b Man), 3.82-3.76 (m, 6H, overlapping H-6a Man, H-3 Glc, H-6a Glc), 3.74 (t, $J$ 9.9, 2H, H-4 Man), 3.66-3.62 (m, 6H, overlapping H-2 Glc, H-4 (Glc), H-5 Glc); ${ }^{13} \mathrm{C}-\mathrm{NMR}(150 \mathrm{MHz}$, $\left.\mathrm{D}_{2} \mathrm{O}\right): \delta 171.2(\mathrm{NHCO}), 136.8(\mathrm{C}), 128.1$ (aromatic $\left.\mathrm{CH}\right), 101.3$ (C-1 Man) 83.0 (C-1 Glc), 77.7, 73.0, 70.8, 70.7, 70.5, 70.0, 66.8 (each CH), 61.0, 60.6 (each $\mathrm{CH}_{2}$ ); HRMS (ES): calcd 835.2596 $[\mathrm{M}+\mathrm{Na}]^{+}$, found 835.2608.

\section{Molecular modelling}

All calculations were carried out using the GB/SA solvation model $^{22}$ for water and the OPLS-AA force field ${ }^{23}$ in Macromodel 8.5. Low energy structures were obtained for both glycophane core macrocycle structures of $\mathbf{2} \mathbf{a}$ and $\mathbf{4 a}$ (not containing the mannose residue by a conformational searching structures sampled) with using the SUMM method. For the purpose of this conformational search $N$-methyl groups were incorporated instead of the $N$-(1-methoxycarbonyl)methylamino-2-oxoethyl) substituents. The structures corresponding to the global minima were subsequently used for the model building. The favoured angles for the dihedrals $\Phi$ and $\Psi$ for the glycosidic linkage between the mannose and glucose/glucuronic acid residues were calculated by systematic exploration of $\Phi$ and $\Psi$ space using the dihedral drive method and also by SUMM based conformational searching techniques, of model disaccharides ${ }^{24}$ with $\alpha(1 \rightarrow 3)$ linkages. The glycosidic torsion $\Phi$ is defined as $\mathrm{H}_{1}-\mathrm{C}_{1}-\mathrm{O}_{3}-\mathrm{C}_{3}$ and $\Psi$ is defined as $\mathrm{C}_{1}-\mathrm{O}_{3}-\mathrm{C}_{3}-\mathrm{H}_{3}$. and the torsion angles observed for the lowest energy conformers were in good agreement with those previously calculated for related disaccharides. ${ }^{25}$ See also the supporting information section of reference $5 c$. These parameters were then used to incorporate the mannose residues on to the macrocyclic scaffold using the build function in Macromodel. The $N$-(1-methoxycarbonyl)methylamino-2-oxoethyl substituent was subsequently incorporated instead of the $N$-methyl group to generate, after a final energy minimisation and superimposition, the structures shown in Fig. 2.

\section{Cell assays}

Cells of the human colon adenocarcinoma line SW480, also treated with $150 \mu \mathrm{M}$ 1-deoxymannojirimycin (Calbiochem, Darmstadt, Germany) for $24 \mathrm{~h}$, the pancreatic carcinoma line Capan-1 and the CHO Lec8 mutant (kindly provided by P. Stanley, Albert Einstein College of Medicine, Bronx, NY, USA) were cultured and processed to monitor lectin-dependent cell staining using biotinylated ConA as probe by quantitative fluorescence detection in a FACScan instrument (Becton-Dickinson, Heidelberg, Germany) with streptavidin/R-phycoerythrin (1:40; Sigma, Munich, Germany) as indicator as described. ${ }^{26}$ Comparative analysis was routinely done with aliquots of the same cell batch, and inter-assay variability in percent did not exceed $12 \%$. 


\section{Acknowledgements}

Generous funding was provided by the European Commission through Marie Curie IntraEuropean Fellowships ((MEIF-CT2003-500748,514958) to SGG and TVT as well as a Marie Curie Research Training Network (contract no. CT-2005-19561), the Programme for Research in Third-Level Institutions (PRTLI), administered by the HEA (of Ireland) for funding, IRCSET and Enterprise Ireland (MT), the research initiative LMUexcellent and the Verein zur Förderung des biologisch-technologischen Fortschritts in der Medizin e. V. (Heidelberg, Germany). We gratefully acknowledge Dr B. Friday, Dr S. Namirha and Dr B. Tab for inspiring discussion.

\section{References}

1 H.-J. Gabius, ed. The Sugar Code. Fundamentals of Glycosciences, Wiley-VCH, Weinheim, 2009.

2 (a) N. Sharon, and H. Lis, in Glycosciences: Status and Perspectives, ed. H.-J. Gabius, and S. Gabius, Chapman \& Hall, London, 1997, pp. 133-162; (b) G. Reuter and H.-J. Gabius, Cell. Mol. Life Sci., 1999, 55, 368-422; (c) H.-J. Gabius, H.-C. Siebert, S. André, J. JiménezBarbero and H. Rüdiger, ChemBioChem, 2004, 5, 740-764; (d) H.-J. Gabius, Crit. Rev. Immunol., 2006, 26, 43-79; (e) S. André, T. Kožár, S. Kojima, C. Unverzagt and H.-J. Gabius, Biol. Chem., 2009, 390, $557-$ $566 ;(f)$ K. Honke, and N. Taniguchi, in The Sugar Code. Fundamentals of Glycosciences, ed. H.-J. Gabius, Wiley-VCH, Weinheim, pp. 385402; $(\mathrm{g})$ C. Zuber, and J. Roth, in The Sugar Code. Fundamentals of Glycosciences, ed. H.-J. Gabius, Wiley-VCH, Weinheim, pp. 87-110.

3 (a) S. André, C. Unverzagt, S. Kojima, X. Dong, C. Fink, K. Kayser and H.-J. Gabius, Bioconjugate Chem., 1997, 8, 845-855; (b) C. Unverzagt, S. André, J. Seifert, S. Kojima, C. Fink, G. Srikrishna, H. H. Freeze, K. Kayser and H.-J. Gabius, J. Med. Chem., 2002, 45, 478-491; (c) S. André, C. Unverzagt, S. Kojima, M. Frank, J. Seifert, C. Fink, K. Kayser, C.-W. von der Lieth and H.-J. Gabius, Eur. J. Biochem., 2004, 271, 118-134; (d) S. André, S. Kojima, I. Prahl, M. Lensch, C. Unverzagt and H.-J. Gabius, FEBS J., 2005, 272, 1986-1998; (e) S. André, T. Kožár, R. Schuberth, C. Unverzagt, S. Kojima and H.-J. Gabius, Biochemistry, 2007, 46, 6984-6995.

4 (a) J. Kopitz, C. von Reitzenstein, S. André, H. Kaltner, J. Uhl, V. Ehemann, M. Cantz and H.-J. Gabius, J. Biol. Chem., 2001, 276, 35917-35923; (b) S. André, H. Sanchez-Ruderisch, H. Nakagawa, M. Buchholz, J. Kopitz, P. Forberich, W. Kemmner, C. Böck, K. Deguchi, K. M. Detjen, B. Wiedenmann, M. von Knebel Doeberitz, T. M. Gress, S.-I. Nishimura, S. Rosewicz and H.-J. Gabius, FEBS J., 2007, 274, 3233-3256; (c) D. D. Marathe, E. V. Chandrasekaran, J. T. Y. Lau, K. L. Matta and S. Neelamegham, FASEB J., 2008, 22, 4154-4167; (d) R. Schwartz-Albiez, in The Sugar Code. Fundamentals of Glycosciences, ed. H.-J. Gabius, Wiley-VCH, Weinheim, pp. 447-468; (e) J. Wang, Z.H. Lu, H.-J. Gabius, C. Rohowsky-Kochan, R. W. Ledeen and G. Wu, J. Immunol., 2009, 182, 4036-4045.

5 (a) M. Avalos, R. Babiano, M. J. Carretero, P. Cintas, F. J. Higes, J. L. Jiménez and J. C. Palacios, Tetrahedron, 1998, 54, 615-628; (b) P. V. Murphy, H. Bradley, M. Tosin, N. Pitt, G. M. Fitzpatrick and W. K. Glass, J. Org. Chem., 2003, 68, 5692-5704; (c) M. Tosin, S. G. Gouin and P. V. Murphy, Org. Lett., 2005, 7, 211-214; (d) M. Tosin and P. V. Murphy, J. Org. Chem., 2005, 70, 4107-4117.

6 (a) I. J. Goldstein, and R. D. Poretz, in The Lectins. Properties, Functions, and Applications in Biology and Medicine, ed. I. E. Liener, N. Sharon, and I. J. Goldstein, Academic Press, San Diego, 1986, pp. 33-247; (b) H. Debray, D. Decout, G. Strecker, G. Spik and J. Montreuil, Eur. J. Biochem., 1981, 117, 41-55; (c) S. K. Patnaik and P. Stanley, Methods Enzymol., 2006, 416, 159-182.

7 R. T. Brown, F. Scheinmann and A. V. Stachulski, J. Chem. Res. (S), 1997, 370-371.

8 M. Upreti, D. Ruhela and R. A. Vishwakarma, Tetrahedron, 2000, 56, 6577-6584.

9 H. Kunz and H. Waldmann, Angew. Chem., Int. Ed. Engl., 1984, 23, $71-72$.

10 (a) T. Velasco-Torrijos and P. V. Murphy, Tetrahedron: Asymmetry, 2005, 16, 261-272; (b) M. Poláková, N. Pitt, M. Tosin and P. V. Murphy,
Angew. Chem., Int. Ed., 2004, 43, 2518-2521; (c) C. O' Brien, M. Poláková, M. N. Pitt, M. Tosin and P. V. Murphy, Chem.-Eur. J., 2007, 13, 902-909.

11 F. Mohamadi, N. G. J. Richards, W. C. Guida, R. Liskamp, M. Lipton, C. Caufield, G. Chang, T. Hendrickson and W. C. Still, J. Comput. Chem., 1990, 11, 440-467.

12 For selected publications on synthesis and applications of glycophanes see: (a) R. R. Bukownik and C. S. Wilcox, J. Org. Chem., 1988, 53, 463 467; (b) J. Jiménez-Barbero, E. Junquera, M. Martin-Pastor, S. Sharma, C. Vicent and S. J. Penades, J. Am. Chem. Soc., 1995, 117, 11198-11204; (c) P. B. Savage, D. William and N. K. Dalley, J. Inclusion Phenom. Mol. Recognit. Chem., 1997, 29, 335-346; (d) J. C. Morales and S. Penades, Angew. Chem., Int. Ed., 1998, 37, 654-657; (e) T. Belghiti, J.-P. Joly, C. Didierjean, S. Dahaoui and Y. Chapleur, Tetrahedron Lett., 2002, 43, 1441-1443.

13 O. Hayashida and I. Hamachi, J. Org. Chem., 2004, 69, 3509-3516.

14 For application of macrocyclic peptides for multivalent ligand display see: (a) V. Wittmann and S. Seeberger, Angew. Chem., Int. Ed., 2000, 39, 4348-4352; (b) T. Ohta, N. Miura, N. Funitani, F. Nakajima, K. Niikura, R. Sadamoto, C.-T. Guo, T. Suzuki, Y. Suzuki, M. Yasuo;, K. Monde and S.-I. Nishimura, Angew. Chem., Int. Ed., 2003, 42, 51865189.

15 (a) D. Pagé, D. Zanini and R. Roy, Bioorg. Med. Chem., 1996, 4, 1949 1961; (b) D. Pagé and R. Roy, Glycoconjugate J., 1997, 14, 345-356; (c) R. Roy, D. Pagé, S. F. Perez and V. V. Bencomo, Glycoconjugate J., 1998, 15, 251-263.

16 (a) S. André, S. Kojima, N. Yamazaki, C. Fink, H. Kaltner, K. Kayser and H.-J. Gabius, J. Cancer Res. Clin. Oncol., 1999, 125, 461-474; (b) G. Rappl, H. Abken, J. M. Muche, W. Sterry, W. Tilgen, S. André, H. Kaltner, S. Ugurel, H.-J. Gabius and U. Reinhold, Leukemia, 2002, 16, 840-845; (c) A. M. Wu, J. H. Wu, J.-H. Liu, T. Singh, S. André, H. Kaltner and H.-J. Gabius, Biochimie, 2004, 86, 317-326; (d) E. I. Park, Y. Mi, C. Unverzagt, H.-J. Gabius and J. U. Baenziger, Proc. Natl. Acad. Sci. U. S. A., 2005, 102, 17125-17129; (e) A. M. Wu, T. Singh, J. H. Wu, M. Lensch, S. André and H.-J. Gabius, Glycobiology, 2006, 16, 524-537; $(f)$ A. Beer, S. André, H. Kaltner, M. Lensch, S. Franz, K. Sarter, C. Schulze, U. S. Gaipl, P. Kern, M. Herrmann and H.-J. Gabius, Cytometry, Part A, 2008, 73A, 139-147; (g) H.-J. Gabius, Biochem. Soc. Trans., 2008, 36, 1491-1498; (h) S. Saussez, S. Cludts, A. Capouillez, G. Mortuaire, K. Smatana Jr., H. Kaltner, S. André, X. Leroy, H.-J. Gabius and C. Decaestecker, Int. J. Oncol., 2009, 34, 433-439; (i) L. Stechly, W. Morelle, A.-F. Dessein, S. André, G. Grard, D. Trinel, M.-J. Dejoghe, E. Leteurtre, H. Drobecq, G. Trugnan, H.-J. Gabius and G. Huet, Traffic, 2009, 10, 438-450.

17 A. Trynda, J. Madoj, A. Konitz and A. Wisniewski, Carbohydr. Res., 2000, 329, 249-252.

18 A. Y. Chernyak, K. V. Antonov and N. K. Kotchetkov, Bioorgan. Khim., 1987, 13, 958-966.

19 A. Y. Chernyak, L. O. Kononov and K. V. Antonov, Bull. Acad. Sci. USSR, Div. Chem. Sci. (Engl. Transl.), 1988, 37, 1475-1482.

20 T. Velasco-Torrijos and P. V. Murphy, Org. Lett., 2004, 6, 3961-3964.

21 (a) M. Tosin, C. O' Brien, G. M. Fitzpatrick, H. Müller-Bunz, W. K. Glass and P. V. Murphy, J. Org. Chem., 2005, 70, 4096-4106; (b) H. Bradley, G. Fitzpatrick, W. K. Glass, H. Kunz and P. V. Murphy, Org. Lett., 2001, 3, 2629-2632.

22 W. C. Still, A. Tempczyk, R. C. Hawley and T. Hendrickson, J. Am. Chem. Soc., 1990, 112, 6127-6129.

23 W. L. Jorgensen, S. D. Maxwell and J. Tirado-Rives, J. Am. Chem. Soc., 1996, 118, 11225-11236.

24 A. Imberty and S. Pérez, Chem. Rev., 2000, 100, 4567-4588.

25 P. E. Jansson, L. Kenne, K. Persson and G. Widmalm, J. Chem. Soc., Perkin Trans. 1, 1990, 591-598.

26 (a) S. André, B. Liu, H.-J. Gabius and R. Roy, Org. Biomol. Chem., 2003, 1, 3909-3916; (b) J. C. Manning, K. Seyrek, H. Kaltner, S. André, F. Sinowatz and H.-J. Gabius, Histol. Histopathol., 2004, 19, 1043-1060; (c) S. André, Z. Pei, H.-C. Siebert, O. Ramström and H.-J. Gabius, Bioorg. Med. Chem., 2006, 14, 6314-6326; (d) S. André, C. E. P. Maljaars, K. M. Halkes, H.-J. Gabius and J. P. Kamerling, Bioorg. Med. Chem. Lett., 2007, 17, 793-798; (e) S. André, F. Sansone, H. Kaltner, A. Casnati, J. Kopitz, H.-J. Gabius and R. Ungaro, ChemBioChem, 2008, 9, 1649-1661; $(f)$ H. Kaltner, D. Solís, J. Kopitz, M. Lensch, M. Lohr, J. C. Manning, M. Mürnseer, M. Schnölzer, S. André, J. L. Sáiz and H.-J. Gabius, Biochem. J., 2008, 409, 591-599; $(g)$ H. Kaltner, D. Solís, S. André, M. Lensch, J. C. Manning, M. Mürnseer, J. L. Sáiz and H.-J. Gabius, Biochemistry, 2009, 48, 4403-4416. 